\title{
ECONOMICS
}

\section{INTERNATIONAL EFFECTS OF CHINA'S RISE AND TRANSITION: NEOCLASSICAL AND KEYNESIAN PERSPECTIVES}

\author{
by
}

Rod Tyers

Business School

University of Western Australia 


\title{
INTERNATIONAL EFFECTS OF CHINA'S RISE AND TRANSITION: NEOCLASSICAL AND KEYNESIAN PERSPECTIVES*
}

\author{
Rod TYERS \\ Business School \\ University of Western Australia, \\ Research School of Economics \\ Australian National University, and \\ Centre for Applied Macroeconomic Analysis (CAMA) \\ Crawford School of Government \\ Australian National University
}
Also CAMA Working Paper No.44-2013
Australian National University
Revised January 2014

Key words:

China, imbalances, saving, monetary policy, spill-overs

JEL Codes:

F42, F43, F47

\section{DISCUSSION PAPER 14.25}

Author best contact details:

Rod Tyers

Winthrop Professor of Economics

UWA Business School

Crawley, WA 6009

Australia

rod.tyers@uwa.edu.au

* Funding for the research described in this paper is from Australian Research Council Discovery Grant No.

DP0557885. Useful discussions on the topic with Dong He, Bert Hoffman, Song Ligang, Paul Luk, Dai Mi, Peter Robertson and Wenlang Zhang are acknowledged, along with comments received at seminars at the China Center for Economic Research, Peking University and the Hong Kong Institute of Monetary Research. Thanks for assistance with data gathering for this research are due to Ying Zhang and Tsun Se Cheong. 


\begin{abstract}
Opinion over the global implications of China's rise is divided between critics, who see it as having developed at the expense of both investment and employment in the US, Europe and Japan and proponents who emphasise improvements in the terms of trade and reductions to the cost of financing that stem from China's supply of light manufactures, its demand for Western capital and luxury goods and its high saving. The criticism implies Keynesian assumptions while proponents take a neoclassical perspective. In this paper, both are embodied in a global macro model that emphasises bilateral linkages via both trade and investment, with monetary spill-overs represented by globally integrated bond markets. Net gains are suggested for the US and Europe from China's successful export-oriented growth, though there are partially offsetting Keynesian effects. China’s recent slower, more consumption focussed growth appears also to be beneficial in those regions and in Japan notwithstanding terms of trade losses.
\end{abstract}




\section{Introduction}

The rise of China and other Asian, heretofore developing, economies since the 1980s has not only underwritten global economic performance but, by cheapening traded light manufactures and supplying substantial excess savings, it has conferred on the developed regions terms of trade gains in both product and financial markets. ${ }^{1}$ Real interest rates on long term instruments peaked in the mid-1980s and have fallen since, in part because of the relative expansion of high-saving regions. Yet the international changes wrought by China have been regarded by critics as having been at the expense of both investment and employment in the US, Western Europe and Japan. Moreover, in the US and Europe at least, through no fault of China's, the cheap credit tended to flow into debt-financed consumption, property and deficit government spending (Chinn et al. 2012). ${ }^{2}$

This pattern of interaction with Asia began to change, first with the slowdown in Japan in the 1990s but more recently with the poor performance of the other large regions after the GFC. It has become clear that the export-led growth model is unsustainable for China, for two main reasons. First its light manufacturing exports now loom large in global trade and there is insufficient market growth for their expansion to continue. Second, the demographic contraction that has already occurred in Japan is now imminent in China. It will reduce the availability of surplus agricultural workers, raising labour costs and slowing productivity growth. The more inward-focussed alternative will be slower because new growth-sustaining reforms must now venture into politically sensitive areas, including the heretofore protected heavy manufacturing and services sectors and the hukou system that constrains labour mobility. Moreover, political stability will dictate that more attention be paid to environmental costs and to controlling income inequality. Importantly, Asia's contribution to global saving will also decline as reforms ensure that Chinese households are offered the choice to consume from more of their corporate income and as populations age, particularly in China and Japan. ${ }^{3}$

Apart from the fact that the world now has much larger East Asian economies than it did in the 1980s, the East Asian slowdown, combined with the decline in excess saving, now offers the rest of the world shocks that are the opposites of the Asian shocks in the decades since. Where

\footnotetext{
${ }^{1}$ The terms of trade gain transmitted financially has been commonly referred to as the Asian "savings glut". To the extent that the glut extended beyond Asia, the major contributors were the petroleum-exporting countries. See Bernanke (2005), Chinn and Ito (2007), Choi et al. (2008) and Ito (2009). Yet the "savings glut” hypothesis has important detractors, whose stories are discussed later in the paper.

${ }^{2}$ Makin and Narayan (2009), while supporting the pretext, use growth accounting to suggest that foreign borrowing also contributed significantly to raising US output and hence living standards prior to the GFC.

3 Japan's long time and substantial excess savings, embodied in its current account surplus, has been trending down in recent years and it fell to zero in the fourth quarter of 2012.
} 
those were deflationary in the developed world, inducing substantial and continuing monetary expansions, these will be inflationary. The inflationary pressure will stem from rising real rates of return that cause private portfolios to cease hoarding money, raising liquidity and price levels. Thus, as a source of reflation, rising Chinese consumption could be one of the Keynesian stimuli required to rescue demand and reduce unemployment queues in the advanced economies. Moreover, it would increase their saving and therefore their investment. For these reasons, and because of the extraordinary scale of sovereign debt in the developed regions, there will be pressure on monetary authorities to accommodate this inflation (Rogoff 2013).

This paper offers a brief review of both the empirical and the modelling literatures concerning the global impact of China's growth to date, along with an analysis of both its retrospective and prospective impacts that employs a global macroeconomic model. The model is structured so as to quantify international effects that stem, on the one hand, from purely neoclassical changes to the product and financial terms of trade and, on the other, from shifts in factor demand in the presence of Keynesian sticky wages. Accordingly, it incorporates bilateral linkages via both trade and investment, with monetary spill-overs represented by globally integrated bond markets. The results are consistent with effects of Chinese growth on the developed regions that are large (Eickmeier and Kuehnlenz 2013) and include reduced employment and investment coinciding with valuable terms of trade gains. With compensation for the displaced and unemployed, however, the results suggest that the pre-transition pattern of China's expansion would have yielded net real income gains in these regions. It is further suggested that the impending Chinese transition to slower, more inward-looking growth will be net beneficial to the US, the EU and Japan and of sufficient magnitude that it could help draw their economies out of stagnation. ${ }^{4}$

The section to follow reviews the empirical and modelling literatures on China's global impacts. Section 3 then briefly describes the pre-GFC pattern of China's growth, the reasons for a transition toward more inward-focussed growth and the consequences of this for China's consumption and saving. The model used for quantitative analysis is then presented in Section 4 and assessments both of pre-GFC growth shocks and post-transition shocks are described in Section 5. Conclusions are offered in Section 6.

\footnotetext{
${ }^{4}$ The results are contrary to those of N'Daye et al (2010) and Genberg and Zhang (2010), who find that the international effects of increased Chinese consumption are small. Their results stem from their use of a model in which spill-over effects stem primarily from trade, and financial flows are only weakly represented.
} 


\section{The Debate over China's Global Impact}

The modern literature on the effects in developed regions of trade with developing ones surged in the late 1980s following a deterioration in the labour market performance of low-skill US and European workers. An extensive survey, grounded in the Stolper-Samuelson Theorem, was offered early on by Wood (1994). The subsequent literature broadened and can be thought of as divided amongst labour economics, global general equilibrium analysis and the combination of applied macroeconomics and international finance.

\section{Labour studies}

The early empirical studies of the links between trade and US labour market performance were by Bound and Johnson (1992), Borjas and Ramey (1994), Berman et al. (1994) and Leamer (1996). These studies apportioned the blame for low wages or low employment of production workers variously between trade with developing countries (including "outsourcing”) on the one hand and labour-saving technical change on the other, with all attributing at least part of the effect to trade. After China's accession to the WTO in 2001, its growth accelerated and it became the dominant developing trading partner. The empirical literature on labour market effects was then resurgent, noting that while production worker performance in the US had been poor from the 1980s into the early 1990s, the performance of all US salary earners (bar the top one per cent) deteriorated after 2000 (Haskell et al. 2012). This new stylised fact has motivated the emergence of labour theories that depend on new models with heterogeneous workers and heterogeneous firms (Helpmann et al 2010, Autor et al. 2013). These tend to suggest a greater role for trade with China than the earlier empirical literature. Yet this literature addresses only labour market outcomes and not whether the developed regions are overall net gainers or losers from China’s expansion.

\section{Global general equilibrium analysis}

The comparative narrowness of the empirical labour approach motivated general equilibrium analysts to address the issue of wage inequality as well as economy-wide net gains or losses from Asian expansion. Global numerical models with neoclassical structures have been used, for the most part ignoring the nominal labour market rigidities common in the developed regions. The early literature begins with Krugman (1995) and proceeds to the decomposition studies by Francois and Nelson (1998) and Tyers and Yang (1997), both of which suggested that strong growth in developing trading partners had been welfare improving in the developed economies and that technical change was more important than trade in determining labour 
market performance. ${ }^{5}$ The labour market results proved, however, to the quite sensitive to the characterisation of technology in global models. If, for example, imports from Asia are significantly differentiated from local products and substantial non-traded service sectors are represented, terms of trade (and hence real income) gains dominate substitution effects, even for low-skill workers (Tokarick 2005). Moreover, in both the developed economies and the growing Asian developing economies wage distribution effects were shown to depend on capital-skill complementarity (Tyers and Yang 2000, Winchester and Greenaway 2007). ${ }^{6}$ Subsequent assessments include that by Dimaranan et al. (2007), which finds gains and losses across other developing regions stemming from growth in China and India, but only small net effects on the developed regions. Francois and Wignaraja (2008) use a similar approach to focus on the implications for the industrial economies of expanded intra-Asian trade. They also find small welfare changes, stemming from terms of trade effects. More recently, Harris et al. (2011) and Harris and Robertson (2013) offer comparative steady state analysis with endogenous skill acquisition in otherwise neoclassical models. Product (though not financial) terms of trade effects are again emphasised with sectoral employment changes very much evident in association with the Rybczinski re-allocations that facilitate net gains. Di Giovanni and Levchenko (2010) and Levchenko and Zhang (2012), employ a more disaggregated modelling approach and emphasise differential productivity growth across industries. Their work follows the empirical tests on industry level productivity growth by Hsieh and Ossa (2011), who find small positive net gains to the rest of the world, again stemming primarily from terms of trade changes. ${ }^{7}$ Di Giovanni et al. (2013) find small net gains for trading partners from China's growth although the distributional effects on workers emerge as large, across industry-specific skill groups. Overall, the newer modelling studies continue to find net welfare gains in the developed regions stemming from growth in Asia in general, and China in particular.

\section{Macroeconomics and international finance}

The early applied macroeconomic assessments of China's growth are divided. On the one hand there are those seeing a sustainable global order with export-oriented growth at the expanding "periphery" and a pattern of monetary policy regimes that mirrors the Bretton Woods agreement (Dooley et al. 2003, 2005, 2011). On the other, many have worried about

\footnotetext{
${ }^{5}$ A similar conclusion is drawn from dynamic global modeling by McKibbin and Woo (2003).

${ }^{6}$ A useful survey of global modeling assessments to this point is by Winchester (2006).

${ }^{7}$ Their approach accommodates the analysis of value chains, known to be significant in China's growth and trade, though it misses the financial implications of value chains exposited by Kalemli-Ozcan et al (2014).
} 
the imbalances associated with the (primarily Asian) "savings glut" and "upstream” financial flows that stem from it. ${ }^{8}$ Critics of China's growth strategy have attributed its contribution to these upstream financial flows to capital market distortions, exchange rate management and myriad other interventions by the all-pervasive Chinese state to confer unfair advantage on Chinese firms and to raise exports and investment at the expense of household consumption. ${ }^{9}$

Adopting the standard "East Asian" growth model, China was able to move workers from rural poverty to urban locations where they could be combined with capital and imported technology, yielding rapid productivity growth. But the modest skills of these workers required the distortion of the product mix in favour of light (labour-intensive) manufactures, unbalancing it relative to consumption and investment demand and thus requiring a rapid expansion in trade. The speed of the growth, combined with lagging social institutions and industrial reform, also induced very high household saving rates and made state owned enterprises very profitable, leading to high corporate saving. This had modest effects on the developed regions prior to the last decade, before which the scale of China's economy did not rival their own. After China's post-WTO accession surge, however, this growth is claimed to have caused flipsides in the developed regions that included high unemployment and slow or non-existent real wage growth, combined with cheap credit, arguably giving rise to asset price booms that ultimately destabilised banking systems, leaving behind an overhang of now-public debt that will be immiserizing in the medium term.

\section{The "savings glut" debate}

The most common concern expressed by the "savings glut" proponents is that the Asian financial crisis caused Chinese and other East Asian policy makers to actively foster saving and to resist subsequent nominal appreciations against the dollar, mainly via reserve accumulation. This, they say, cheapened credit, particularly in the US, precipitating the GFC. ${ }^{10}$ It is, thus, a single decade story, but it has many detractors. Key opponents of this note that surges in

\footnotetext{
${ }^{8}$ The literature asserting, and depending on, the "savings glut" hypothesis is now extensive. Contributions include Bernanke (2005, 2011), Caballero et al. (2008), Caballero (2009), Chinn and Ito (2007), Choi et al. (2008), Chinn et al (2012), Eichengreen (2004) and Lee and McKibbin (2007).

${ }^{9}$ The American literature critical of China's macroeconomic policies is also extensive. Bernanke $(2005,2011)$ offers the outline and Krugman (2010) declares that "China is making all of us poorer". The US macroeconomic position is put in more detail by, amongst others, Lardy $(2006,2012)$ and Bergsten et al. (2008). Similar advocacy of policy-induced "balance” in China’s growth can be found, still more formally, in Blanchard and Giavazzi (2006), while it is also recognised that some of the US reaction is mercantilist (Ito 2009).

${ }^{10}$ Caballero (2009) refines the link between investment demand from Asia and US financial adjustment, by formalising the suggestion of Bernanke that excess demand for "financial quality" pushed up the prices of US long term bonds and induced the US financial sector to package assets of lower quality in ways that could meet this demand.
} 
inflows and declines in domestic yields were not always coincident. They include Laibson and Mollerstrom (2010), Borio and Disyatat (2011) and Shin (2011). Laibson and Mollerstrom see the GFC as the bursting of a bubble that did not require cheap Chinese credit to initiate. Borio and Disyatat see it, more particularly, as depending on the pattern of gross financial flows into and out of the US, with a particular focus on European flows. This view is formalised by Shin, who notes large expansions in the balance sheets of key European banks in the decade post the EMU, their very substantial role in financial intermediation in the US market and the comparatively lax capital standards imposed on them by European regulators. It is this, says Shin, rather than the net financial inflow from China, Japan and OPEC, that gave rise to a cheapening of US credit.

\section{The longer term effects of Asian saving}

The global effects of high saving in Asia go beyond the decade central to these stories. As emphasised by the World Bank (2013), of the addition to global GDP since 1980, measured in US dollars at current exchange rates, a third is due to Asian growth. At the same time Asian economies have contributed about half of the corresponding increment to global saving, with China contributing fully a third of the increment since 1990 (Table 1). Even before China's recent surge, Asia was a major contributor to global saving growth, as Figure 1 suggests. This is evidence that the shift in global growth toward high-saving Asia, which occurred in the 1980s, accelerated the rate at which the global savings supply curve shifted to the right. If the corresponding global investment demand curve shifted by less there would have been a decline in the Wicksellian (1898) "natural” rate of interest at the global level.

If one accepts the segmentation theory of the yield curve, which suggests that the long market matches savers to investors with portfolios dominated by long instruments while (at least under conventional monetary policy) the short market serves monetary policy and country-specific financial services, then the trend in long rates is suggestive of the change in the underlying global natural rate. ${ }^{11}$ He and McCauley (2013) find evidence of "imperfect substitutability along the yield curve” and use it to explore monetary policy spill-over effects, which they see as enlarged by the global integration of long bond markets. Ito (2013: 8) offers support for this view. He argues that as a result of financial globalisation, domestic financial markets are more susceptible to international factors and that tends to decouple short-term and long-term rates. Consistent with Bernanke (2005), he concludes that the long-term interest rate is tied down by

\footnotetext{
${ }^{11}$ This can be inconsistent with the expectations theory of the yield curve, which remains most popular notwithstanding the criticisms of it (Shiller et al. 1983).
} 
global saving imbalances and hence reflects the natural rate of interest. This reasoning, and that of Rey (2013), both imply that, when there is free capital mobility, there is inter-regional arbitrage going at the long end of the yield curve whereas the short end of the yield curve is controlled by monetary authorities. ${ }^{12}$ Support for this international arbitrage at the long end is suggested by the time paths of long yields in Figure 2. It follows, then, that the rise in Asian saving is a possible explanation for the persistent downward trend in long term bond rates since the 1980 s that is also apparent from Figure $2 .^{13}$

If this is true, irrespective of the debate over the causes of the GFC, the impending changes in the pattern of Chinese growth and its saving rates have important implications for global financial markets and economic performance in the developed regions. Let us turn to these likely changes.

\section{China's Domestic Transition: Slower Growth and Less Excess Saving}

Although its rate of expansion during its three decades of reform has been spectacular, it is only in the last decade that China's economic size has paralleled those of the US, the EU and Japan. China's exports have grown especially rapidly since the turn of the century and now dominate world trade in light manufactures. ${ }^{14}$ As of 2011 its unadjusted share of global GDP was greater than Japan's and its shares of global exports, saving and investment were larger than those of the US and close to those of the EU (Table 2).

Looking forward, there is not the scope for the rest of the world to absorb export growth from China at historical rates. Moreover, there has been an accelerated rise in Chinese labour costs, foreshadowing a Lewis "turning point"15, which is associated with the depletion of mobile labour in rural areas and a nation-wide demographic contraction stemming from China's “one child” policy. Superficially, it would seem that a switch from export-oriented to inwardfocussed growth should be possible, just by sustaining high investment and substituting

\footnotetext{
${ }^{12}$ I thank Paul Luk for clarifying this point.

${ }^{13}$ The separation of the series for Japan is associated with its long term current account surplus and the major Yen appreciation shocks of the late 1980s and early 1990s, which established a negative risk premium amongst Japanese savers. In all regions, inflation rates were low throughout the period shown in the figure and so the trend of nominal long rates reflects that of corresponding real rates.

${ }^{14}$ According to trade data from data.worldbank.org, Chinese manufactured exports now sum to more than a third of the collective manufactured imports of the US, the EU and Japan, to which level growth has been extraordinary since 2001, when China's share was only seven per cent.

${ }^{15}$ The timing of China's Lewis turning point is a subject of controversy, as suggested by the contrasts between the views expressed by: Cai (2010), Garnaut (2010) and Golley and Meng (2011), which offer just a sampling of a substantial literature. There is, however, little doubt that the turning point is on its way, even if there is little agreement as to whether recent real wage rises suggest its presence.
} 
consumption for exports. But this has been problematic because the growth to date has emphasised light manufacturing while China's growing middle class demands quality products and services that are as yet poorly represented in its production basket. To diversify China's output toward these products requires major reform of its heavy manufacturing and services sectors and investment in associated human capital. ${ }^{16}$

Yet there is potential for substantial new growth from domestic sources. This stems, in particular, from the extension of industrial reforms into hitherto protected heavy manufacturing and services industries, where reductions in costs and prices could have major stimulatory effects on the economy as a whole. Such reforms include further pure privatisation, the fragmentation of state-owned enterprises to induce more competitive pricing, price cap regulation and greater access to services and heavy manufacturing by foreign investors. Oligopoly rents earned in these sectors are linked to corporate saving (Kuijs 2006, Song et al. 2011), which was last measured in the region of a fifth of GDP. Industry policy reforms that foster further privatisation, or that otherwise reduce oligopoly rents, are readily shown to reduce the aggregate level of Chinese saving by amounts sufficient to eliminate its current account surplus (Tyers 2012).

\section{Excess Saving}

National saving includes that by households, corporations and government. Savings that exceed the value of domestic private and public investment ("excess savings”) result in the net acquisition of foreign assets and they are measured by the current account surplus:

$$
C A=S_{H H}+S_{C}+(T-G)-I=S_{D}-I=\Delta R-F I_{\text {Inward }}+F I_{\text {Outward }}=X-M+N
$$

Here $S_{H H}$ is household saving, $S_{C}$ is corporate saving, (T-G) is government saving or the fiscal surplus, $S_{D}$ is total domestic saving, $I$ is investment (including public investment), $\Delta R$ is official foreign reserve accumulation, $C A$ is the current account balance and $N$ is net foreign factor income. ${ }^{17}$ FI signifies foreign investment, inflows or outflows. In China's case these terms are dominated by FDI since cross-border portfolio investments are restricted by its capital controls (Ma and McCauley 2007). ${ }^{18}$ Thus, to explore the implications for external

\footnotetext{
${ }^{16}$ For a discussion of the institutional and industrial reform agenda and its difficulty, see for example Riedel (2011) and Deer and Song (2012).

${ }^{17}$ This identity is readily obtained by combining the expenditure identity, $Y=C+I+G+X-M$ with the disposal identity for GNP, $Y+N=C+T+S$, where $S=S_{H H}+S_{C}$.

${ }^{18}$ The substitution between reserve accumulation, which takes the form of low-yielding foreign (mostly US) government bonds and likely better yielding portfolios of the CIC and increasing levels of outward investment by
} 
accounts we must consider changes to household saving, corporate saving and government saving and compare these with changes in investment.

\section{Household saving}

The pattern and time trend of household saving in China and other Asian economies is analysed by Horioka and Wan (2007) and Horioka and Terada-Hagiwara (2012). They point out that the three main determinants of rates of measurable household saving are the age structure of the population and the levels of income and financial sector development. Saving rates follow a concave path, rising in the early stages of development and subsequently declining with ageing and financial development, which lowers credit constraints. China, this suggests, is in the declining phase; a point with which Yang (2012) agrees, suggesting a range of mainly social and trade policy reforms that will see reduced incentives for household saving many of which are stated priorities of the new Chinese government.

Indeed, recent studies question China's official statistics on consumption expenditure, suggesting that it is larger and growing more quickly than indicated (Ma and Yi 2010). Huang et al. (2012), for example, use the weighted average of consumption-related retail sales growth and service sales growth to project the consumption share of GDP. Their results suggest that it climbed from 49 to 54 per cent during 2008-2010, while China's NBS has it falling from 48 to 47 per cent. $^{19}$

Thus, there is much to suggest a declining path for China's household saving rate. Opposing voices include Wei and Zhang (2011) and Wen (2011). Wei and Zhang identify a link between saving and entrepreneurship effort on the one hand and China’s increasingly inflated sex ratio on the other. The coincidence of son preference and sexual selection technology has seen a rise in the number of unmatched men and increasingly competitive behaviour by families with sons. Debate continues about the strength of this force for higher saving against those associated with policy reforms in the education, health and retirement insurance industries. Wen, on the other hand, employs a model of rapid growth with constant proportional idiosyncratic risk, following Modigliani and Cao (2004), to conclude that saving will continue to rise with income per capita. The assumption of constant proportional risk is a strong one, however, in the face of social reforms to health and retirement systems.

Chinese firms (Economist 2013) is causing a redirection of China's excess saving away from the US. This point is not considered here but is taken up by Sheng (2011) and Tyers et al. (2013).

${ }^{19}$ Huang et al. start with the official consumption share in 2000 and derive the GDP shares in remaining years using real GDP growth and their estimated consumption growth rates. Using similar data, Garner and Qiao (2013) suggest that Chinese consumption expenditure is officially underestimated by US\$ 1.6 trillion, also concluding that its GDP share is expanding. 


\section{Corporate saving}

National accounts "flow of funds" data show corporate saving to be fairly stable at about a fifth of GDP through 2009. In the period since, and looking forward, changes in total corporate saving might be anticipated for three reasons. First, to the extent that slower global growth since the GFC has affected profitability in the state sector, corporate savings might be expected to have also declined in recent years. Second, on-going industrial policy reforms, which include the subdivision of some SOEs, are likely to have further reduced profitability and hence corporate saving. Finally, financial development and the integration of formal and informal financial markets across the country have been proceeding apace. With more options and more security in the management of funds, it might be expected that the trend of corporate saving would be downward.

\section{Government saving}

Since the implementation of China's tax law in 1994, the domestic economy has gradually integrated, with an increasing share of economic activity taking place in the "formal sector". This has meant that central government tax revenue has grown steeply, at a rate that is notably faster than GDP. ${ }^{20}$ Along with this, central government financial surpluses have expanded continuously. At the same time, however, with the maintenance of capital controls, financial integration has caused China's high-saving households and firms to deposit their savings in domestic commercial banks. These banks have a long tradition of lending to SOEs and provincial governments, where in effect, debt has been underwritten centrally. The comparatively recent development in this lending is an expansion in the share directed to provincial governments to finance local public investment. ${ }^{21}$ As shown in Figure 3, this has grown significantly since 2002 and it accelerated with the onset of the GFC and the government's plan to increase public works expenditure when export demand fell away temporarily. After 2007, the sum of the provincial deficits exceeded the central surplus, leading to a return to overall deficits with magnitudes expanding to unprecedented levels. Thus, government saving is also shifting in the negative direction in the post-GFC years.

\footnotetext{
${ }^{20}$ According to China's NBS Statistical Yearbook (2012), central government revenue has expanded its share of nominal GDP from 10\% in 1994 to 23\% in 2012.

${ }^{21}$ This is notwithstanding central government sharing of national revenue with the provinces at a 50-50 rate in 2011.
} 


\section{Excess saving relative to investment}

The above discussions lead us to expect a declining trend in China's total domestic saving rate though this is not yet fully represented in the official statistics, which thus far show only a slight decline since 2010. Since then, however, total (private and public) investment has risen to nearly half of GDP. Indeed, the growth rate of completed investment in fixed assets was 24 and 20 per cent in 2011 and 2012, still much faster than recorded GDP growth. This underlies the continuously rising investment share of GDP shown in Figure 4 and it confirms the prediction by Lee and McKibbin (2007) that investment would contribute substantially to China's "rebalancing”. The result has been a contracting current account surplus in the postGFC period, though China's surplus remained the single largest across individual countries in $2012 .^{22}$

Looking ahead, it is difficult to imagine a higher rate of investment without the prospect of increasingly wasteful projects. Moreover, the recent boost in public investment has stemmed from national post-GFC stimulus policy, the preference on the part of commercial banks to lend to protected provincial governments and SOEs and the substantial excess supply of saving, bottled up in the home market by capital controls. All three conditions should fade through time, so that the implications for future excess saving will then depend on the differences between the rates of decline of private saving on the one hand and investment on the other.

A key factor in this trend will be China's commitments to the internationalisation of the renminbi and toward capital account opening. Clearly, this will lead to greatly expanded private holdings of foreign financial assets in both directions but there is no suggestion that it will greatly affect the level and growth rate of either China's total saving or its total investment (He and Luk 2013, Tyers and Zhang 2011). He et al. (2012), in particular, envision a trend toward trade balance, offset in the current account by higher yields on foreign (newly private) holdings. Continued decline in excess saving therefore appears the most likely future course, not just because this is the apparent path since 2010 but also considering the trend toward financial deepening, the prospect of further social and industrial reform and the mounting evidence that consumption expenditure is growing faster than officially estimated.

${ }^{22}$ IMF, IFS Database. 


\section{Assessing Chinese Growth Shocks Pre and Post Transition}

The approach taken is to estimate the effects on the developed regions of pre-transition, export oriented Chinese growth shocks and compare these with the corresponding effects of anticipated post-transition shocks that exhibit slower growth and reduced excess saving. The analysis addresses short run departures from the underlying long run growth path of the global economy. A multi-region general equilibrium structure is used that allows the option of neoclassical and Keynesian closures. To capture the effects of international financial flows it is assumed that the private financial products (equities) of each region are differentiated and that portfolio managers assign new net saving across regions so as to maximise expected portfolio returns given this differentiation. This approach retains Feldstein-Horioka (1980) home bias while allowing significant redirections in financial flows at the margin.

At the same time, an integrated global bond market is envisioned that gives rise to a global "natural" rate of interest that equates global saving with global investment in US dollars. ${ }^{23}$ Regional rates depend also on region-specific risk premia which, in turn, are responsive to comparative fiscal profligacy. No initial steady state is presumed and so real regional rates of return on equity investments depart from regional bond yields, though the real bond yields represent the opportunity cost of consumption and investment and their nominal counterparts represent the opportunity cost of holding regional money. Financing rates are therefore affected by monetary policy in every region, reflecting the high rate of monetary spill-over that is characteristic of modern "unconventional" monetary policy.

Within each region the demand for money is driven by a "cash in advance" constraint applying across the whole of GDP. For any one household, home money is held in a portfolio with long maturity equities and bonds and the latter are claims over physical capital across the regions and domestic government debt. ${ }^{24}$ Six regions are identified: the US, the EU, Japan, China, Australia and the Rest of the World, though the focus of this paper is on the first four. ${ }^{25}$ Each region supplies a single product that is also differentiated from the products of the other regions. On the supply side, there are three primary factors with "production" labour $(L)$ a partially unemployed variable factor while the stocks of physical capital $(K)$ and skill $(S)$ are

\footnotetext{
${ }^{23}$ A version of the model with regionally segmented bond markets is also available. Needless to say, spill-overs from saving and monetary policy shocks are smaller in this version. The version presented here is regarded as closer to current global norms dominated as they are by unconventional monetary policy in the major advanced economies.

${ }^{24}$ Expectations are exogenous in the model and are formed over future values of the home price level, the rate of inflation, the real rate of return on home assets and nominal disposable income.

${ }^{25}$ The EU is modeled as the full 26 and it is assumed that this collective has a single central bank.
} 
fixed and fully employed. Collective households are net savers with reduced form consumption depending on current and expected future disposable income and the home interest rate. Aggregate consumption is subdivided via a single CES structure between the products of all the regions. The more routine details of the model are provided in Appendix 1.

The direction of net saving to equity investments at home and abroad

Here the modelling departs from convention by incorporating explicit portfolios of regional assets. Data on regional saving and investment for 2011 is first combined with that on international financial flows to construct an initial matrix to allocate total domestic saving in each region to investment across all the regions. From this is derived a corresponding matrix of initial shares of region i's net (private and government) saving that are allocated to investment in region $j, i_{i j}^{S 0}$. When the model is shocked, the new shares are calculated so as to favour investment in regions, $j$, with comparatively high expected real rates of return, $r^{c e}$, and/or comparatively low rates of capital income taxation. Expected real rates of return depend on the current real rate of return on installed capital and, via interest parity, expected changes in real exchange rates:

$$
r_{i}^{c e}=r_{i}^{c}+\hat{e}_{i}^{e}=\frac{P_{i}^{P} M P_{i}^{K}}{P_{i}^{K}}+\hat{e}_{i}^{e}=r_{i}^{c} \gamma_{i}^{e},
$$

where $P_{i}^{K}$ is the price of capital goods, which are not distinguished from the regional good in this model and equal to $P_{i}^{P}$, the producer price. ${ }^{26}$ Shocks to the exogenous factor, $\gamma_{i}^{e}$, can represent changes in either the relative cost of capital goods or in the expected real exchange rate.

Region $i$ 's portfolio manager allocates the proportion $i_{i j}^{S}$ of its annual (private plus government) saving to new investments, which might be thought of as equity issued in regions $j$, such that $\sum_{j} i_{i j}^{S}=1 .{ }^{27}$ Because the newly issued equity is differentiated across regions based on un-modelled and unobserved region-specific properties, their services are combined via a constant elasticity of substitution (CES) function specific to each regional portfolio manager.

\footnotetext{
${ }^{26}$ The producer price level is the factor door price of the regional good, which differs in this model from the GDP price level due to indirect taxation. See Appendix 1 for an explanation of this.

${ }^{27}$ The manager does not re-optimise over total holdings every year. This is because the model is deterministic and risk is incorporated only via exogenous premia, so the motivations for continuous short run rebalancing, other than the arrival of new saving, are not represented.
} 
Thus, region $i$ 's household portfolio management problem is to choose the shares, $i_{i j}^{S}$, of its private saving net of any government deficit, $S_{i}^{D}=S_{i}^{P}+T^{D}+T^{I}-G$, which are to be allocated to the assets of region $j$ so as to maximise a CES composite representing the value of the services yielded by these assets:

$$
\max _{\substack{i_{i j}^{S} \\ \text { a }}} U_{i}^{F}=S_{i}^{D}\left[\sum_{j} \alpha_{i j}\left(i_{i j}^{S}\right)^{-\rho_{i}}\right]^{-\frac{1}{\rho_{i}}} \text { such that } \sum_{j} i_{i j}^{S}=1 \text {. }
$$

Here $\alpha_{i j}$ is a parameter that indicates the benefit to flow from region $i$ 's investment in region $j$. The CES parameter, $\rho_{i}$, reflects the preparedness of region $i$ 's household to substitute between the assets it holds. To induce rebalancing in response to changes in rates of return the $\alpha_{i j}$ are made dependent on Tobin's Q like ratios of after-tax expected rates of return on installed capital in destination regions, $j$, and current market real financing interest rates in the region of origin, $r_{j}^{c e}$ and $r_{i}$, via: ${ }^{28}$

$$
\alpha_{i j}=\beta_{i j}\left(\frac{r_{j}^{c e} / \tau_{j}^{K}}{r_{i} / \tau_{i}^{K}}\right)^{\lambda_{i}} \quad \forall i, j, \quad \lambda_{i}>0 \quad \forall i
$$

Here, $\tau_{i}^{K}$ is the power of the capita income tax rate in region $i$. This relationship indicates the responsiveness of portfolio preferences to rates of return, via the (return chasing) elasticity $\lambda_{i}$. The allocation problem, thus augmented, is:

$$
\max _{\substack{i_{i j}^{S}\\}} U_{i}^{F}=S_{i}^{D}\left[\sum_{j} \beta_{i j}\left(\frac{r_{j}^{c e} / \tau_{j}^{K}}{r_{i} / \tau_{i}^{K}}\right)^{\lambda_{i}}\left(i_{i j}^{S}\right)^{-\rho_{i}}\right]^{-\frac{1}{\rho_{i}}} \text { such that } \sum_{j} i_{i j}^{S}=1 \text {. }
$$

Solving for the first order conditions we have, for region $i$ 's investments in regions $j$ and $k$ :

$$
\frac{i_{i j}^{S}}{i_{i k}^{S}}=\left(\frac{\beta_{i j}}{\beta_{i k}}\right)^{\frac{1}{1+\rho_{i}}}\left(\frac{r_{j}^{c e} / \tau_{j}^{K}}{r_{k}^{c e} / \tau_{k}^{K}}\right)^{\frac{\lambda_{i}}{1+\rho_{i}}}
$$

This reveals that region i's elasticity of substitution between the bonds of different regions is $\sigma_{i}^{I}=\lambda_{i} /\left(1+\rho_{i}\right)>0$. This elasticity has two elements. The return-chasing behaviour of region

\footnotetext{
${ }^{28}$ Note that region $i$ 's market bond yield, $r_{i}$, is determined concurrently and indicates the replacement cost of capital in region $i$ and therefore the opportunity cost for region $i$ 's household of investment in region $j$.
} 
i's household $\left(\lambda_{i}\right)$ and the imperfect substitutability of regional bonds, and therefore the sluggishness of portfolio rebalancing $\left(\rho_{i}\right)$.

The optimal share of the net domestic saving of region $i$ that is allocated to equity in region $j$ then follows from (6) and the normalisation condition, that $\sum_{k} i_{i k}^{S}=1$ :

$$
i_{i j}^{S}=\frac{1}{\sum_{k}\left(\frac{\beta_{i k}}{\beta_{i j}}\right)^{\frac{\sigma_{i}^{I}}{\lambda_{i}}}\left(\frac{r_{k}^{c e} / \tau_{k}^{K}}{r_{j}^{c e} / \tau_{j}^{K}}\right)^{\sigma_{i}^{I}}} .
$$

The key matrix for calibration is $\left[\beta_{i j}\right]$. These elements are readily available, first, by noting that only relative values are required and hence, for each region of origin, $i$, one value can be set to unity, and second, by making the assumption that the initial database has the steady state property that the net rates of return in regions $j$ are initially the same as the market bond yield, $r_{j}$. Then, since in the base data $r_{i j}^{e 0}=r_{j}^{0}, r_{i k}^{e 0}=r_{k}^{0}$, the $\beta_{i j}$ s are available from a modified (6): Note that the tax rate on capital income would not enter this relationship if investment were financed in the destination region, since it is assumed the tax would apply to all types of financial capital earnings incurred in that region, at the same rate. The assumption here, however, is that it is financed in the region of origin and so, considering that tax rates differ across regions, these differences are accounted for by the added quotients.

Total investment spending in region $j$, in $j$ 's local currency, is then:

$$
I_{j}=\sum_{i}\left(i_{i j}^{S} S_{i}^{D} \frac{E_{i}}{E_{j}}\right),
$$

Where $E_{i}$ is the nominal exchange rate of region $i$ relative to the US\$, which is the numeraire in the model $\left(E_{U S}=1\right)$.

\section{Global financial equilibrium and real financing interest rates}

The global bond market is integrated by ensuring that the sum of investment spending worldwide must equal the sum of domestic saving worldwide, each valued in US\$.

(9) $\quad \sum_{i} I_{i} E_{i}=\sum_{i} S_{i}^{D} E_{i}$. 
This scalar condition determines a global interest rate to clear financial markets, $r^{W}{ }^{29}$

Regional financing yields are then set relative to this rate using an interest premium factor, $\varphi_{i}$, that is defined relative to $r_{U S}\left(\varphi_{U S}=1\right)$, and the effects of varying sovereign risk are incorporated via dependence on the fiscal balance:

$$
r_{i}=r^{W} \varphi_{i}, \quad \varphi_{i}=\varphi_{i}^{0}\left[\left(\frac{G_{i}}{T_{i}} / \frac{G_{U S}}{T_{U S}}\right)\right]^{\phi_{i}}, \quad \forall i \neq " U S ",
$$

Here $\phi_{i}$ is an elasticity indicating sensitivity to sovereign risk.

\section{Regional money market equilibrium}

A cash-in-advance constraint is assumed to generate transactions demand for home money across all components of GDP. The opportunity cost of holding home money is set at the nominal after-tax yield on home long term bonds. Real money balances are measured in terms of purchasing power over home products.

$$
m_{i}^{D}=a_{i}^{M D}\left(y_{i}\right)^{\varepsilon_{i}^{M Y}}\left(\frac{r_{i}\left(1+\pi_{i}^{e}\right)}{\tau_{i}^{K}}\right)^{-\varepsilon_{i}^{M R}}=\frac{M_{i}^{S}}{P_{i}^{Y}} .
$$

Here y is real regional GDP, $P^{Y}$ is the GDP price and $\pi_{i}^{e}$ is the expected inflation rate of the consumer price level, $P^{C}$, defined in Appendix 1. The nominal money supply, $M^{S}$, can be set as an exogenous policy variable or endogenous to a price level or exchange rate target.

\section{Model database, parameters and operation}

The model database is built on national accounts as well as international trade and financial data for the global economy in 2011. The details are provided in Appendix 2. Solutions require a choice of shocks and closures, the latter allowing the determination of the labour market equilibrium in each region (fixed or flexible nominal wage), the fiscal policy regime (fixed nominal or real government expenditure or fixed deficit) and the monetary policy regime (whether the target is the price level, the exchange rate or the money supply itself). These are detailed in Appendix 3.

\footnotetext{
${ }^{29}$ Since investment in this model is simply allocated saving, equations (22) and (23), combined with the normalisation condition on the shares, might be thought of as forming a tautology (global saving = global saving), and this would be the case in a real model with a single numeraire. Here the key condition is that the global financial market must clear in a single currency. In this case, when there are more than two regions, the equations are not tautological and meaningful results emerge for the global market clearing interest rate.
} 


\section{Effects of Chinese Growth and Saving}

Two sets of experiments are conducted. The first concerns the effects of the continuation in 2011 of Chinese growth on the pattern of the past decade - export driven with comparatively low consumption growth. The second examines the transition to slower overall growth and a rising consumption share of GDP. This analysis is undertaken using two different closures, as indicated in Table 3. The first is neoclassical, with nominal wages sufficiently flexible in all regions to clear labour markets and no changes to nominal government saving, the latter implying that any changes in revenue from taxes at exogenous rates is committed to government expenditure. The second is Keynesian, with rigid nominal wages of production workers in the US, EU, Japan and China and full employment in the rest of the world. Government spending is fixed in nominal terms in the US, EU and Japan but government saving is fixed in the other regions, and, for monetary policy, all central banks are assumed to target the monetary base. ${ }^{30}$ Expectations over prices, exchange rates and rates of return are exogenous and, in the results presented, short run changes in these variables are surprises. ${ }^{31}$

\section{Effects of continued export led growth beyond 2011}

The growth shocks listed in Table 4 are constructed as stylised representation of the comparative performance of the Chinese economy in 2002-2007. ${ }^{32}$ The shock to consumption captures the observed decline in the share of consumption expenditure and the rise in the share of private savings in GDP. In the first experiment, shocks are applied only to China and these are to productivity, consumption behaviour and the stock of capital and skill. In addition, there is a Chinese monetary expansion that allows for domestic inflation at a rate that is roughly representative of the pre-transition period. In the second simulation, monetary responses are also allowed in the large developed regions, even though these regions enjoy no comparative growth shocks. The magnitude of these expansions is set to arrest the resulting deflation in the US and EU and to reduce but not eliminate it in Japan, where active deflation (mainly of producer prices and the GDP deflator) continued throughout the pre-transition period.

\section{Implications of Chinese growth under neoclassical assumptions}

\footnotetext{
${ }^{30}$ While closures with price level and exchange rate targets are available, in the results presented monetary policy responses are introduced via exogenous shocks.

${ }^{31}$ Solutions with model-consistent expectations over price levels, exchange rates and private disposable incomes are available. Not surprisingly, the main difference is that these yield smaller increments to Chinese saving. It is unlikely that a majority of Chinese agents expected the growth surge to continue indefinitely, however, and so these results are not presented formally.

32 The capital accumulation and productivity shares of China’s recent growth are controversial (Krugman 1994). The numbers used here are broadly consistent with the meta-analysis by Wu (2011).
} 
Two simple stories dominate the results, which are summarised in Table 5. First, the key feature of the comparative growth shocks is that the Chinese expansion is unbalanced as between production and consumption. It therefore causes excess supply abroad and, so long as there is no foreign monetary response, makes goods relatively abundant compared with money and so is deflationary. Another way to see the deflation effect is to note that the rise in China's excess saving causes a decline in the global underlying natural rate of interest. There is a portfolio shift toward money, the supply of which is fixed, and so the relative price of goods falls. The second story is that lower interest rates increase consumption and reduce saving in the advanced regions. Home bias, combined with higher productivity in China, causes their corresponding levels of investment to decline, with negative consequences for future growth. China's real exchange rate is an indicator of the terms of trade in a model with single regional products, yet its role is more subtle. The growth shocks and monetary expansion in China deliver a nominal depreciation relative to the other major currencies, which is not surprising given the fixed money supplies abroad. But the terms of trade is just one of two main forces affecting China's real exchange rate, reflecting the fact that more Chinese output lowers the relative value of Chinese products in global markets. The second concerns financial flows on the balance of payments. China's consumption is comparatively small relative to its GDP and its trade dependence, including its import penetration, is comparatively high. At the same time, the presence of outward capital controls means that, notwithstanding a substantial outflow of reserves and officially sanctioned foreign investment, the share of its saving that is directed abroad is comparatively small. Indeed, despite the inclusion of return-chasing behaviour, the dominant home bias effects on investment tend to constrain the free movement of saving from all regions. This means that Chinese growth with high saving tends to have a demand switching effect; to limit globally open consumption (and so reduce outflows on the trade account) and concentrate expenditure on mainly domestic investment. This tends to appreciate the real exchange rate. ${ }^{33}$ In the end, the results show that the second force is dominated by the first when output growth is strong.

When monetary responses are allowed in the large developed regions bond-buying by central banks further reduces real interest rates. The monetary expansions required to eliminate deflation are large, considering that there is no real growth in these economies. With mitigated

\footnotetext{
${ }^{33}$ The characterization of China's consumption spending as more internationally open than its saving is accurate, at least by comparison with the other regions, though it is accentuated in the model used here by the lack of multiple products and input-output behaviour and hence by the absence of China's "value chain" links with other developing economies.
} 
deflation their real consumption growth rises less and so the losses in real saving and investment are smaller. Nominal incomes rise in the US and the EU with their monetary expansions and the real purchasing power of these incomes over their home consumption bundles rises, albeit more modestly.

\section{Implications of Chinese growth under Keynesian assumptions}

Here the nominal wage is set as exogenous in China and the developed regions. In China, allowance is made for representative growth in the nominal wage of production workers as part of the growth shocks. ${ }^{34}$ Again, two simple stories dominate the results, which are summarised in Table 6. First, with no shocks to the economies outside China, including to monetary policy, the unbalanced Chinese growth shocks advance net supply abroad and so are deflationary there. With nominal wage rigidities, this deflation reduces employment and output in the advanced economies. As for the neoclassical case: the alternative perspective on the deflation is that increased Chinese excess saving reduces global long term interest rates, inducing a substitution toward money in portfolios, causing the value of output to fall relative to the fixed supplies of money. Also as before, the second story is that reduced interest rates increase consumption and reduce saving in these regions and the power of home bias ensures that their levels of investment also decline, with negative consequences for future growth. The immediate impact on their economies is a substantial negative employment shock and reduced real GDP. Yet the terms of trade gain is so large that the purchasing power over their home consumption bundle is still expanded, at least for the US and the EU. Thus, these regions are net gainers from pre-transition Chinese growth, but the impacts are domestically unequal. When monetary responses are introduced in the large developed regions, the real contractions in those regions are eliminated or greatly reduced. With smaller employment losses the neoclassical effects are more dominant and the net real income gains more substantial. Of course, this is excepting Japan, where the monetary expansions undertaken were, in reality, insufficient to eliminate all deflation. As before, the relative global abundance of Chinese goods is the dominant force. In the long run, however, the net short run gains from the terms of trade change might be expected to be offset by the effective diversion of investment to China.

\footnotetext{
${ }^{34}$ The nominal wage shock indicated in Table 4 is smaller than the recorded growth in Chinese average wages. In this model, production workers are homogeneous and the skilled wage is endogenous and is lifted substantially by the growth shocks.
} 


\section{Effects of slower Chinese growth and higher consumption beyond 2011}

This analysis combines slower productivity and factor accumulation changes with a single shock to Chinese preferences that boosts consumption and reduces saving (Table 4). ${ }^{35}$ The preference shock might be thought of as stemming from the combination of life cycle changes and the social and industrial reforms discussed in earlier sections and is set sufficient to raise the consumption share of GDP by about a tenth (from 45 to near 50 per cent). An accompanying monetary expansion is introduced that is just sufficient to deliver modest growth in the real production wage of unskilled workers (or, in the Keynesian analysis, modest increases in production employment).

\section{Implications of Chinese post-transition growth under neoclassical assumptions}

As the summary in the third block of Table 5 suggests, the shift to faster consumption growth, in particular, has marked effects on economic performance abroad. The two stories of the previous growth discussion now emerge in reverse. China's expansion continues unbalanced but, this time it adds excess demand for goods in the rest of the world. With no monetary response there, this causes goods to become more scarce than money and hence inflation. Alternatively, reduced Chinese saving causes a substantial real rise in interest rates in all the other regions, causing portfolio rebalancing away from money, thus raising liquidity. With fixed nominal money supplies this depresses the value of money relative to goods. The resulting inflation is modest but positive and, under neoclassical assumptions, it boosts firm revenues and nominal wage costs equally. Turning again to the second story, the higher interest rates also induce private agents in the other regions to reduce consumption, raising both home saving and, with dominant home bias, also home investment. ${ }^{36}$ The opposite occurs in China, so there is a significant relocation of investment from China to the developed regions even though, under the neoclassical closure, the volume of output is unaltered everywhere in the short run.

The associated changes in real exchange rates are, however, not a simple reversal of the growth results. Changes in relative product abundance now favour the other regions, and so are appreciating for China. Yet, this time, these are more than offset by the domestic demand switching effects of increased Chinese consumption (much of which is from abroad) and

\footnotetext{
35 The slowdown assumed here is consistent with the analysis by Feng and Yang (2013), though this is not to deny that considerable potential remains for further productivity growth, even in China's manufacturing sector (Hsieh and Klenow 2009).

${ }^{36}$ The interest rate rise is small in China because its interest premium falls. This is because China is relatively dependent on indirect taxes and these bear mainly on consumption. So when consumption is raised relative to saving, government revenue increases.
} 
reduced (domestically focussed) saving, causing a small net Chinese real depreciation and hence a further, albeit modest, terms of trade gain in the other regions.

\section{Implications of Chinese post-transition growth under Keynesian assumptions}

These results, presented in the third block of Table 6, offer a more realistic context in which the change in Chinese consumption behaviour might take place. Yet, for the developed regions at least, the pattern of the results is the same as in the neoclassical case. For them, the Chinese consumption surge is a significant Keynesian stimulus. The inflation might be seen, alternatively as due to excess demand for goods relative to money to the interest rate rise and the liquidity increase that comes with portfolio rebalancing. This modest inflation is, by assumption, not resisted by central banks. ${ }^{37}$ This time, workers are drawn out of unemployment, raising real output by up to a per cent and employment by substantially more. Once again, home bias sees both saving and investment rise in the developed regions. For China, however, the results differ in that the home interest rate actually falls and this induces much less Chinese inflation, thus avoiding the substantial nominal depreciation observed in the neoclassical case. This occurs because China's interest premium falls due the departure from the neoclassical assumption of fiscal balance. China is comparatively dependent on indirect taxes and these bear mainly on consumption. So when consumption is raised relative to other forms of expenditure on GDP, government revenue increases substantially. With fixed nominal government spending this yields a substantial surplus that reduces the premium.

The real exchange rate changes are similar to the neoclassical case, with the relative growth shocks ensuring continued relative abundance of Chinese products reinforcing the demand switching effects to yield a modest Chinese real depreciation, conferring on the other regions a modest terms of trade gain. The shift from continued export-led, low-consumption growth to more inward-focussed growth under Keynesian conditions is seen to cause Chinese real GDP growth to slow by 4.5 percentage points while that in the larger regions is faster by one percentage point. The differences in real consumption and investment are starker. In China, real consumption growth is faster by eight percentage points while that in the US is slower by six. But investment in China is slower by 12 percentage points, while that in the US is faster by 28. This suggests a significant shift in the global centre of gravity of production and growth, away from China and toward the other large regions.

\footnotetext{
${ }^{37}$ A potential downside not considered in this paper is that a rise in the underlying natural rate of interest would see a considerable enlargement in the cost of servicing government debt, which will be of particular importance in the US, Europe and Japan, where net interest on sovereign debt now absorbs at least a tenth of government revenue (OECD Economic Outlook 89 Database).
} 
To make the comparison even more clear it is instructive to convert the labour use effects in Table 6 to production worker numbers in employment. This difference amounts to a relative gain of 17 million employees across the US, the EU and Japan and a relative loss of 16 million modern sector employees in China. This large gain notwithstanding, the effects of China's slowdown on the real purchasing power of incomes is very positive for Japan but the US and the EU did better under employment-robbing pre-transition growth. What this suggests is that net real income gains to the US and EU from economic change in China will continue, if more modestly, but with added benefits in the post-transition period from growing employment and hence less distributional stress.

\section{Contrasting neoclassical and Keynesian Assumptions}

A summary of the results under neoclassical and Keynesian closures is offered in Table 7. In the neoclassical case, the omission of employment effects does not significantly distort the estimated net real income gains from pre-transition Chinese growth, at least as to direction. It does, however, reverse the sign of net effects on real income in the US and EU from posttransition Chinese growth. If, under Keynesian assumptions, central banks in the US, the EU and Japan allow some inflation, then the employment gains are sufficient to more than offset the terms of trade losses. Both model formulations agree as to the direction of the effects due to the Chinese transition, at least when measured in terms of real incomes. The employment gains in the US, the EU and Japan, along with the increases in saving and investment indicated in Tables 6 and 7, suggest that the outlook beyond China's transition will be positive for all the developed regions.

On the other hand, China's modern sector will add fewer workers each year and enjoy significantly slower yet still positive output growth, with the real purchasing power of national income over the home consumption bundle stagnating. Indeed, though not shown in the tables, the comparative rise of consumer price inflation in China would erode gains in the real consumption wage there, even though the unit cost of low-skill labour to firms rises. Clearly, in the new era the distributional stress will fall on China rather than the older developed regions.

\section{Conclusion}

A substantial literature has developed on the effects of China's growth on other regions the labour and macroeconomics components of which suggest pessimism as to foreign gains. The 
global modelling component of this literature has been neoclassical in orientation and so focussed on terms of trade gains that have stemmed from China's cheap light manufacturing exports and its excess saving. It has therefore been comparatively sanguine about the global benefits from China's rise. In this paper the Keynesian or “job stealing” aspect of Chinese growth is incorporated in a simple short run global model to shed light on the comparative effects of terms of trade and employment changes.

In just the same way that the case for free trade over autarky in a small economy requires compensation to achieve a Pareto improvement, the case for positive benefits outside China from its expansion requires gainers (the skilled and capital owners) to compensate losers (low skill workers). The simulation results suggest that the effects of China's growth on the terms of trade and employment in the developed regions are indeed in conflict yet, at least for the US and the EU, positive net gains in real income emerge, irrespective of the monetary responses of these regions. The key effect of the surge in China's growth after 2001 appears to have been to confront these regions with distributional stress and therefore major policy challenges.

Because the economic performance of its main trading partners has been poor in the decade since its accession to the WTO, and particularly poor since the GFC, and because relative costs have risen more quickly in its domestic markets, China has undertaken a turn "inward” in search of sources of sustained growth and continued transformation. This turn inward has begun to reduce China's excess saving. Eventually, the extension of financial and industrial reforms into hitherto protected sectors will see reduced corporate saving. At the same time, life cycle changes associated with its impending demographic contraction will cause household saving to decline as well. Indeed, the most likely pattern is one of slower GDP growth combined with faster consumption growth. The consequences of this for the other large economies with which China trades have both neoclassical and Keynesian elements.

Since China (and, indeed, the collective of China and Japan) will soon cease to be net purchasers of foreign sovereign debt, bond yields will rise globally, coming at a time when global portfolios will seem heavy with cash as the seeds of real recovery emerge in the US and Japan. When rebalancing occurs in favour of higher yielding instruments there will be a surge in liquidity and a tendency to inflation which, if allowed by central banks, could deliver a significant stimulus in the languid economies of the developed regions. According to this analysis, this stimulus could raise real GDP growth by a percentage point. Moreover, while the loss of excess saving will raise interest rates globally, this will encourage a switch from consumption to saving in the financially open Western economies. And considering the strong 
association of domestic saving with domestic investment, this, in turn, will raise investment in physical capital and reinforce the resurgence of growth. Of course, there is a zero-sum aspect to this, since the simulation results suggest that the annual shocks associated with such a switch would return 17 million production workers to employment in the US, the EU and Japan. In the unlikely event that Chinese semi-redundant rural workers are still available in sufficient numbers this would imply that the flow to modern sector employment slows by 16 million. While these effects appear to be dominated by Keynesian employment redistribution, the same analysis with a neoclassical closure delivers a largely consistent bottom line, at least when welfare is measured by the purchasing power of national incomes over home consumption bundles. The post-transition growth pattern in China tends to resolve the earlier conflict of forces abroad so that the US, the EU and Japan are projected to enjoy increases in both employment and real national incomes. On the other hand, slower growth in China will confront its policy makers with distributional conundrums that could be more serious, since vast numbers of poor Chinese still await their urban opportunities.

In the interpretation of these results a number of issues arise that are the subject of on-going research. First, the distribution of government revenue burdens over direct and indirect taxes, and amongst the forms of indirect tax, is quite important in determining the projected behaviour of consumer, producer and GDP price levels. The abstraction adopted here, that indirect taxes fall on consumption and imports only, may prove to be a strong one as it affects the behaviour of both firms and households in important ways. Second, the model assumes a single homogeneous good in each region, side-stepping the popular issue of "value chain" effects in China's trade behaviour. In association with this, there is some enlargement of the role of Chinese consumption in providing foreign stimulus. These aspects of the results require validation empirically and via simulations using a more detailed model, though they do not discount the main message, that the neoclassical global modelling work on the impacts of Chinese growth cannot be discounted and that post-transition Chinese growth should offer the rest of the world further stimulus in a mix that is less inclined to create distributional conflict.

\section{References}

Autor, D.H., D. Dorn and G.H.Hanson (2013), “The China syndrome: local labor market effects of competition in the United States", American Economic Review, forthcoming.

Bergsten, C.F., C. Freeman, N.R. Lardy and D.J. Mitchell (2008), China's Rise: Challenges and Opportunities, Washington DC: Peterson Institute for International Economics. 
Berman, E., J. Bound and Z. Griliches (1994), “Changes in the demand for skilled labour within US manufacturing: evidence from the annual survey of manufactures”, Quarterly Journal of Economics, 109(2): 367-397.

Bernanke, B.S. (2005), “Remarks by the Governor”, Sandridge Lecture, Virginia Association of Economists, Richmond Virginia, March, Federal Reserve Board. (2009), “The crisis and the policy response”, Stamp Lecture, London School of Economics, London, England, January 13.

(2011), “Global imbalances: links to economic and financial stability”, speech given at the Banque de France Financial Stability Review Launch Event, Paris, France February 18.

Blanchard. O. and F. Giavazzi (2006), "Rebalancing growth in China: a three-handed approach," China and the World Economy, Institute of World Economics and Politics, Chinese Academy of Social Sciences, 14(4): 1-20.

Bound, J. and G. Johnson (1992), "Changes in the structure of wages in the 1980s: an evaluation of alternative explanations”, American Economic Review, 82(3): 371-392.

Borio, C. and P. Disyatat (2011), "Global imbalances and the financial crisis: link or no link", BIS Working Paper 346, Basel, May.

Caballero, R.J. (2009), “The 'other' imbalance and the financial crisis”, MIT Working Papers in Economics 9-32, Cambridge MA, December.

Caballero, R.J., E. Farhi and P.O. Gourinchas (2008), “An equilibrium model of 'global imbalances’ and low interest rates”, American Economic Review, 98(1): 358-393.

Cai, F. (2010), "Demographic transition, demographic dividend and Lewis turning point in China”, China Economic Journal, 3(2): 107-119, September.

Chinn, M.D., B. Eichengreen and H. Ito (2012), "Rebalancing global growth", in O. Canuto and D. Leipziger (eds), Ascent after Descent: Regrowing Economic Growth after the Great Recession, Washington DC: World Bank: 35-86.

Chinn, M.D. and H. Ito (2007), “Current account balances, financial development and institutions: assaying the world 'saving glut'”, Journal of International Money and Finance, 26: 546-569.

Choi, H., N.C. Mark and D. Sul (2008), "Endogenous discounting, the world saving glut and the US current account”, Journal of International Economics, 75: 30-53.

Corden, W.M. and S.J. Turnovsky (1983), "Negative International Transmission of Economic Expansion”, European Economic Review 20: 289-310, June.

Corden, W.M. (1985), “On Transmission and Co-ordination under Flexible Exchange Rates,” in W.H. Buiter and R.C. Marston (eds.) International Economic Policy Co-ordination. Cambridge, U.K.: Cambridge University Press.

Deer, L. and L. Song (2012), “China’s approach to rebalancing: a conceptual and policy framework”, China \& World Economy, 20(1): 1-26.

di Giovanni, J. and A.A. Levchenko (2010), "Putting the parts together: trade, vertical linkages, and business cycle comovement," American Economic Journal: Macroeconomics, 2 (2): 95-124, April.

di Giovanni, J., A.A. Levchenko and J. Zhang (2013), “Global welfare effect of China: trade integration and technical change’, AER Macroeconomics, October. 
Dimaranan, B. E. Ianchovichina and W. Martin (2009), "How Will Growth in China and India Affect the World Economy?” Review of World Economics, 145(33):551-571.

Dooley, M., D. Folkerts-Landau and P. M. Garber (2003), "An Essay on the Revived Bretton Woods System," NBER Working Paper no. 9971.

Dooley, M. and P. Garber (2005), "Is it 1958 or 1968? Three Notes on the Revived Bretton Woods System," Brookings Papers on Economic Activity 1, pp.147-187.

Dooley, M.P., P.M. Garber and D. Folkerts-Landau (2011), "Bretton Woods II still defines the international monetary system," NBER Working Paper 14731, February.

Economist, The (2013), “ODI-lay hee-ho: the expanding scale and scope of China's outward direct investment”, 19 January: http://www.economist.com/news/china/21569775expanding-scale-and-scope-chinas-outward-direct-investment-odi-lay-hee-ho.

Eichengreen, B. (2004), "Global Imbalances and the Lessons of Bretton Woods," NBER, Working Paper 10497, Cambridge Mass: National Bureau of Economic Research.

Eickmeier, S. and M. Kuehnlenz (2013), “China’s role in global inflation dynamics”, Discussion Paper 7-2013, Deutsche Bundesbank.

Feldstein, M. and C.Y. Horioka (1980), "Domestic Saving and International Capital Flows," Economic Journal, Royal Economic Society, 90(358): 314-29, June.

Feng, C. and L. Yang (2013), “The end of China’s demographic dividend”, Ch.4 in R. Garnaut, C. Fang and L. Song (eds), China: a New Model for Growth and Development, Canberra: ANU E Press and Beijing: Social Sciences Academic Press: 55-74.

Francois, J.F. and D. Nelson (1998), “Trade, technology and wages: general equilibrium mechanics, Economic Journal, 108: 1483-99.

Francois, J.F. and G. Wignaraja (2008), "Economic implications of Asian integration," Global Economy Journal, 8 (3): 1-48, September.

Garnaut, R. (2010), “Macroeconomic implications of the turning point”, China Economic Journal, 3(2): 181-190, September.

Garner, J. and H. Qiao (2013), “China - household consumption most likely US1.6 trillion larger than officially stated”, Asian Insight, Morgan Stanley Research, 28 February 2013, http://www.morganstanleychina.com/views/121217.html.

Genberg, H. and W. Zhang (2010), “Can China save the world by consuming more?” VOX EU, 25 April.

Golley, J. and Meng, X. (2011), “Has China run out of surplus labour?” Chinese Economic Review, 22(4): 555-572.

Harris, R.G. and P.E. Robertson (2013), "Trade, wages and skill accumulation in the emerging giants”, Journal of International Economics, 89(2): 407-421, March.

Harris, R.G, P.E. Robertson and J. Xu (2011), “The international effects of China's trade and education booms”, The World Economy, 34(10): 1703-1725.

Haskel, J., R.Z. Lawrence, E.E. Leamer and M.J. Slaughter (2012), "Globalization and U.S. Wages: Modifying Classic Theory to Explain Recent Facts," Journal of Economic Perspectives, American Economic Association, 26(2): 119-40, Spring.

He, D. and P. Luk (2013), “A model of Chinese capital account liberalization”, Hong Kong Institute for Monetary Research Working Paper No.12/2013. 
He, D. and R.N. McCauley (2013), “Transmitting global liquidity to East Asia: policy rates, bond yields, currencies and dollar credit”, Hong Kong Institute for Monetary Research Working Paper No.15/2013, BIS Working Papers 431, Bank for International Settlements, October.

He, D., L. Cheung, W. Zhang and T. Wu (2012), "How would capital account liberalization affect China's capital flows and renminbi real exchange rates?" China and the World Economy, 20(6): 29-54, November.

Helpman, E., O. Itskhoki and S.J. Redding (2010), "Inequality and Unemployment in a Global Economy,” Econometrica 78(4): 1239-83.

Horioka, C.Y. and A. Terada-Hagiwara (2012), “The determinants and long term projections of saving rates in developing Asia”, Japan and the World Economy, 24: 128-137.

Horioka, C.Y. and J. Wan (2007), "The determinants of household saving in China: a dynamic panel analysis of provincial data." Journal of Money, Credit and Banking 39(8): 2077-96.

Hsieh, C.T. and P. Klenow (2009), "Misallocation and manufacturing TFP in China and India", Quarterly Journal of Economics 124: 1403-1448, November.

Hsieh, C.T and R. Ossa (2011), “A global view of productivity growth in China," NBER Working Paper No. 16778.

Huang, Y., J. Chang and L. Yang (2012), “Consumption recovery and economic rebalancing in China”, prepared for the Asian Economic Panel, March 22-23, Seoul, Korea, published in Asian Economic Papers, 12(1): 47-67, Winter/Spring 2013.

Ito, H. (2009), “US current account debate with Japan then, and China now”, Journal of Asian Economics, 20: 294-313.

(2013), "Monetary policy in Asia and the Pacific in the post, post-crisis era", presented at the 36th Pacific Trade and Development (PAFTAD) Conference, "Financial Development and Cooperation in Asia and the Pacific,” Hong Kong Monetary Authority, November 19-21, 2013.

Jin, Y. (2011), “Income inequality, consumption and social-status seeking”, Journal of Comparative Economics 39,191-204.

Kalemli-Ozcan, S., S. Kim, H.S.Shin, B.E. Sorensen and S Yesiltas (2014) "Financial shocks in production chains”, presented at the American Economic Association meetings, January.

Knell, M. and H. Stix (2006), "Three decades of money demand studies: differences and similarities," Applied Economics, 38(7): 805-818.

Krugman, P. (1994), “The myth of Asia’s miracle”, Foreign Affairs, 73(6): 62-78, Nov-Dec. (1995), “Growing world trade: causes and consequences”, Brookings Papers, 1: 327377.

(2010) “Capital export, elasticity pessimism and the renminbi (wonkish)” New York Times (blog), 16 March.

Kuijs, L. (2006), “How will China’s saving-investment balance evolve?” World Bank Policy Research Working Paper 3958, Beijing, July.

Laibson, D. and J. Mollerstrom (2010), “Capital flows, consumption booms and asset bubbles: a behavioural alternative to the savings glut hypothesis”, The Economic Journal, 120: 354-374, May. 
Lardy, N.R. (2006), ‘Toward a consumption-driven growth path” Policy Brief 06-6, Washington DC: Peterson Institute for International Economics.

Lardy, N.R. (2012), Sustaining China's Growth after the Global Financial Crisis, Washington DC: Peterson Institute for International Economics, January.

Leamer, E.E (1996), "Wage inequality from international competition and technological change: theory and country experience," American Economic Review, American Economic Association, 86(2): 309-14, May.

Lee, J.W. and W.J. McKibbin (2007), "Domestic investment and external imbalances in East Asia”, CAMA Working Paper 4-2007, Canberra: Australian National University.

Levchenko, A.A. and J. Zhang (2012), “The global labor market impact of emerging giants: a quantitative assessment”, paper presented at the 13th Jacques Polak Annual Research Conference, hosted by the IMF, Washington DC, November 8-9.

Ma, G. and R.N. McCauley (2007), “How effective are China’s capital controls?”, Chapter 14 in R. Garnaut and L. Song (eds), China: Linking Markets for Growth, Asia-Pacific Press, July: 267-289.

Ma, G. and W. Yi (2010), “China’s high saving rate: myth and reality”, International Economics, 122: 5-40.

Makin, A.J. and P.K. Narayan (2009), "Has international trade in saving improved US economic welfare?” The Economic Record, 85(S1): S2-S9, September.

McKibbin, W.J. and P. Wilcoxen (1995), "The theoretical and empirical structure of the GCubed model”, Economic Modelling, Elsevier, 16(1): 123-148, January.

McKibbin, W.J. andW.T. Woo (2003), "The consequences of China's WTO accession for its neighbors,"Asian Economic Papers, MIT Press, 2(2): 1-38.

Modigliani, F. and S. Cao (2004), “The Chinese saving puzzle and the life-cycle hypothesis”, Journal of Economic Literature, 42(1), 145-170.

N'Daiye, P., P. Zhang and W. Zhang (2010), “Structural reform, intra-regional trade, and medium-term growth prospects of East Asia and the Pacific-perspectives from a new multi-region model”, Journal of Asian Economics, 21: 20-36.

Rey, H. (2013), “Dilemma not trilemma: the global financial cycle and monetary policy independence”, Federal Reserve Bank of Kansas City Economic Symposium at Jackson Hole, August.

Riedel, J. (2011), “The slowing down of long term growth in Asia: natural causes, the middle income trap and politics”, School of Advanced International Studies, Johns Hopkins University.

Rogoff, K. (2013), “Inflation is still the lesser evil”, Project Syndicate, 6 June 2013, http://www.project-syndicate.org/commentary/, accessed 12 June 2013.

Shiller, R. J., J.Y. Campbell and K.L. Schoenholtz (1983), "Forward rates and future policy: interpreting the term structure of interest rates", Brookings Papers on Economic Activity, 1983(1): 173-223.

Shin, H.S. (2011), “Global Banking Glut and Loan Risk Premium”, Presented at the 12th Jacques Polak Annual Research Conference Hosted by the International Monetary Fund, Washington, DC, November 10-11. 
Song, L., J. Yang and Y Zhang (2011), “State-owned enterprises’ outward investment and the structural reform in China”, China and the World Economy, 19(4): 38-53.

Teles, P. and R. Zhou (2005), “A stable money demand: Looking for the right monetary aggregate", Economic Perspectives, Federal Reserve Bank of Chicago, Q I:50-63.

Tokarick, S. (2005), “Quantifying the impact of trade on wages: the role of non-traded goods”, Review of International Economics, 13(5): 841-860.

Tseng, W., H.E. Khor, K. Kochhar, D. Mihaljek and D. Burton.(1994), "Economic reforms in China: a new phase”, IMF Occasional Paper No. 114, Washington DC.

Tyers, R. (2012), “Looking inward for transformative growth in China”, CAMA Working Paper No. 15/2012, Centre for Applied Macroeconomics, Australian National University, Canberra, March.

Tyers, R. and Y. Yang (1997), “Trade with Asia and skill upgrading: effects on labor markets in the older industrial countries”, Review of World Economics, 133(3): 383-418, September. (2000). "Capital-Skill Complementarity and Wage Outcomes Following Technical Change in a Global Model”, Oxford Review of Economic Policy 16: 23-41.

Tyers, R. and Y. Zhang (2011), “Appreciating the renminbi”, The World Economy, 34(2): 265297, February.

Tyers, R., Y. Zhang and T.S. Cheong (2013), “China’s saving and global economic performance”, Ch 6 in Garnaut, R., F. Cai and L. Song (eds,) China: A New Model for Growth and Development, Canberra: ANU E Press.

Wei, Shang-Jin and Xiaobo Zhang (2011) "The competitive saving motive: evidence from rising sex ratios and saving rates in China” Journal of Political Economy 199(3): 51164.

Wen Jiabao, (2011), Report on Work of the Government, www.npc.gov.cn, 5 March, accessed 24 March 2011.

Wen, Y. (2011), “Explaining China’s trade imbalance puzzle”, Federal Reserve Bank of St Louis, Working Paper 2011-018A, St Louis, August.

Wicksell, K. (1898), Interest and prices: a study of the causes regulating the value of money, Translation from German, London: Macmillan, 1936.

Winchester, N. (2006), “Trade and rising wage inequality: what can we learn from a decade of computable general equilibrium analysis?" In: D. Greenaway, R. Upward and P. Wright (eds), Globalisation and Labour and Market Adjustment, Palgrave Macmillan, Basingstoke, pp. 54-72.

Winchester, N. and D. Greenaway (2007), "Rising wage inequality and capital-skill complementarity," Journal of Policy Modeling, 29(1): 41-54.

Wood, A. (1994), North-South Trade, Employment and Inequality, Oxford: Clarendon Press.

World Bank (2013), Capital for the Future: Saving and Investment in an Interdependent World, Washington DC, 147 pp.

Wu,Y. (2011), “Total factor productivity growth in China: a review”, Journal of Chinese Economic and Business Studies, 9(2): 111-126.

Yang, D.T. (2012), “Aggregate savings and external imbalances in China”, Journal of Economic Perspectives, 26, 4, 125-146. 
Figure 1: Global, Asian and Chinese Saving in US\$ (Log indices 1980=100)

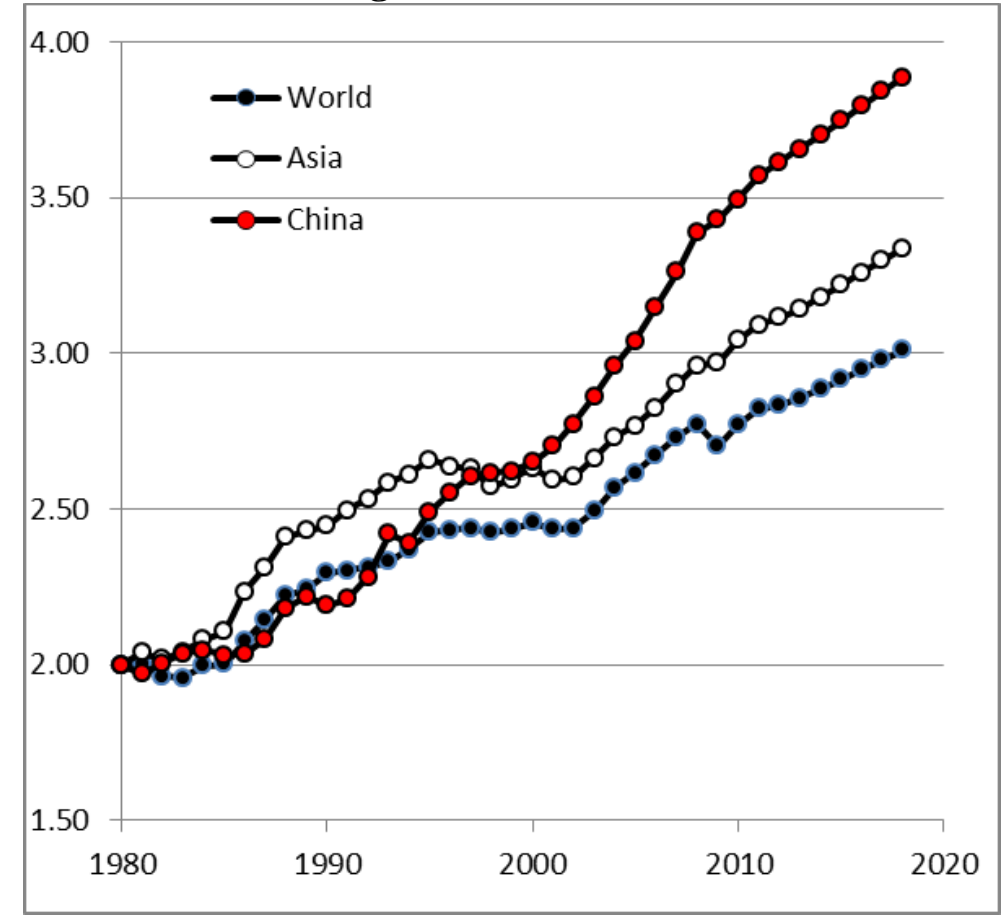

Source: IMF World Economic Outlook Database.

Figure 2: Long Term Bond Yields in Advanced Economies

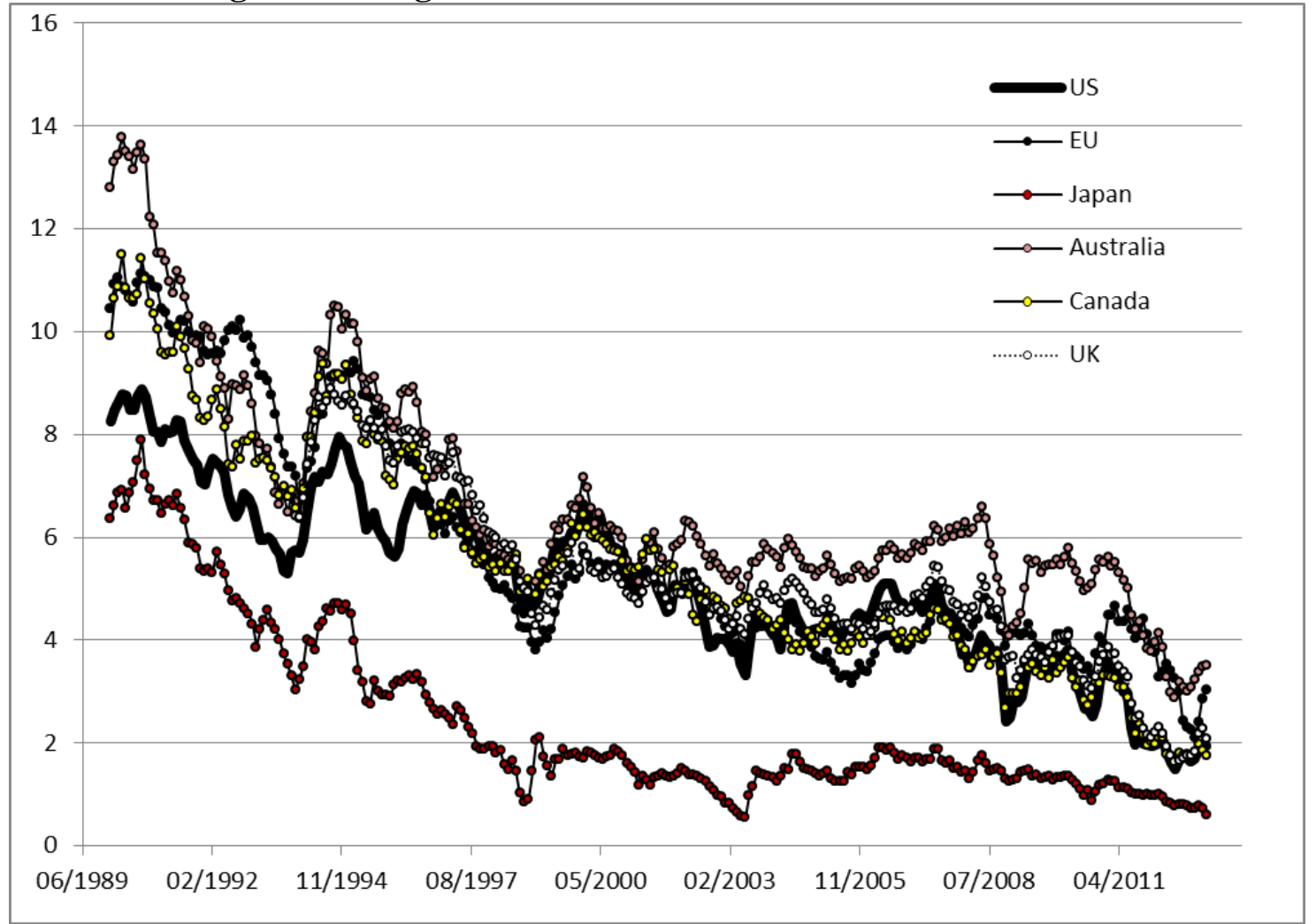

Sources: Bank of Canada, Bank of England, European Central Bank, Reserve Bank of Australia, US Federal Reserve. 
Figure 3: China’s Governments’ Net Surpluses, US\$ Billions

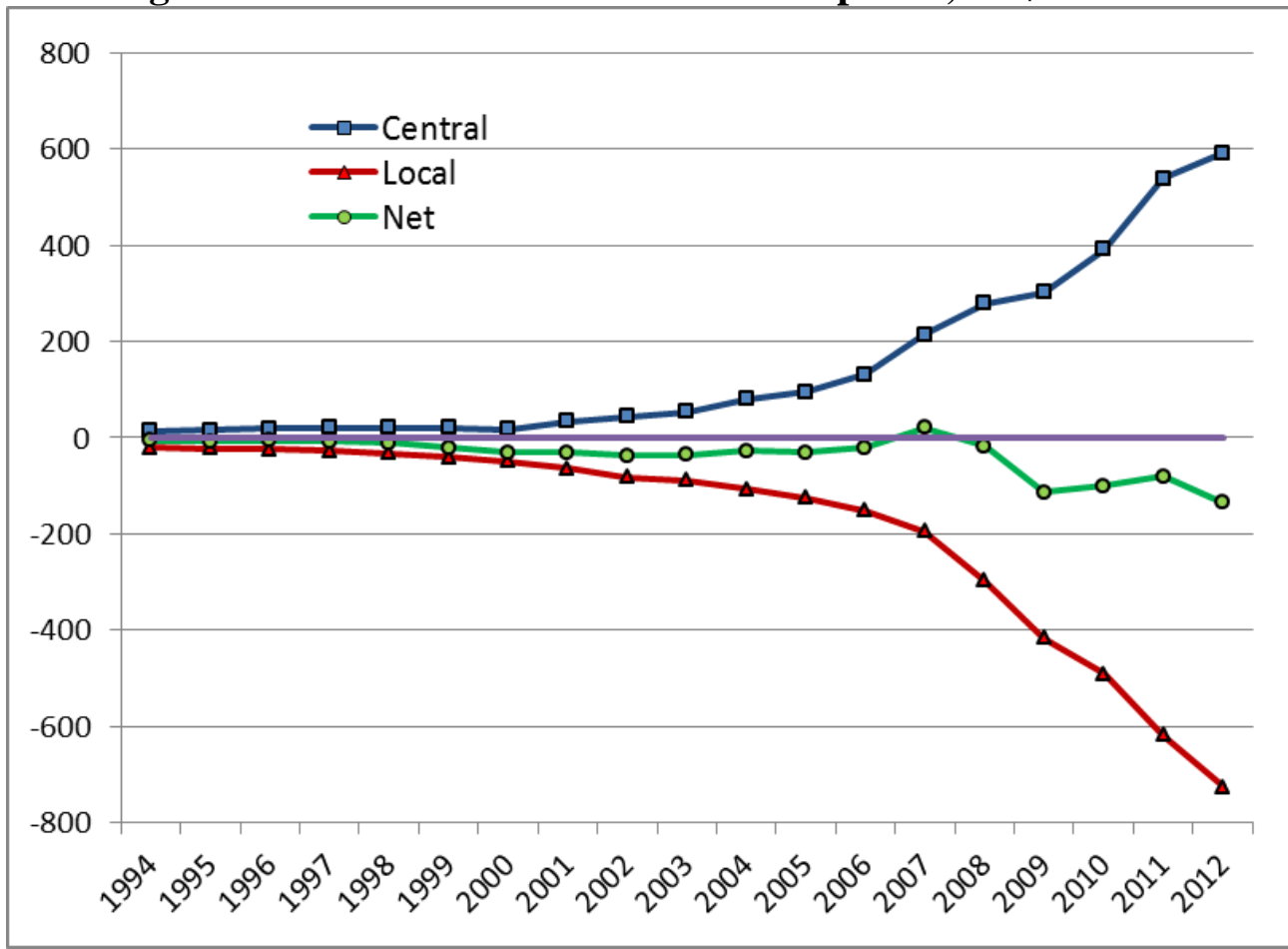

Sources: Government debt and general government gross debt position, IMF Fiscal monitor; External debt outstanding, Chinese statistical yearbook 2012.

Figure 4: China's Saving Surplus, \% GDP

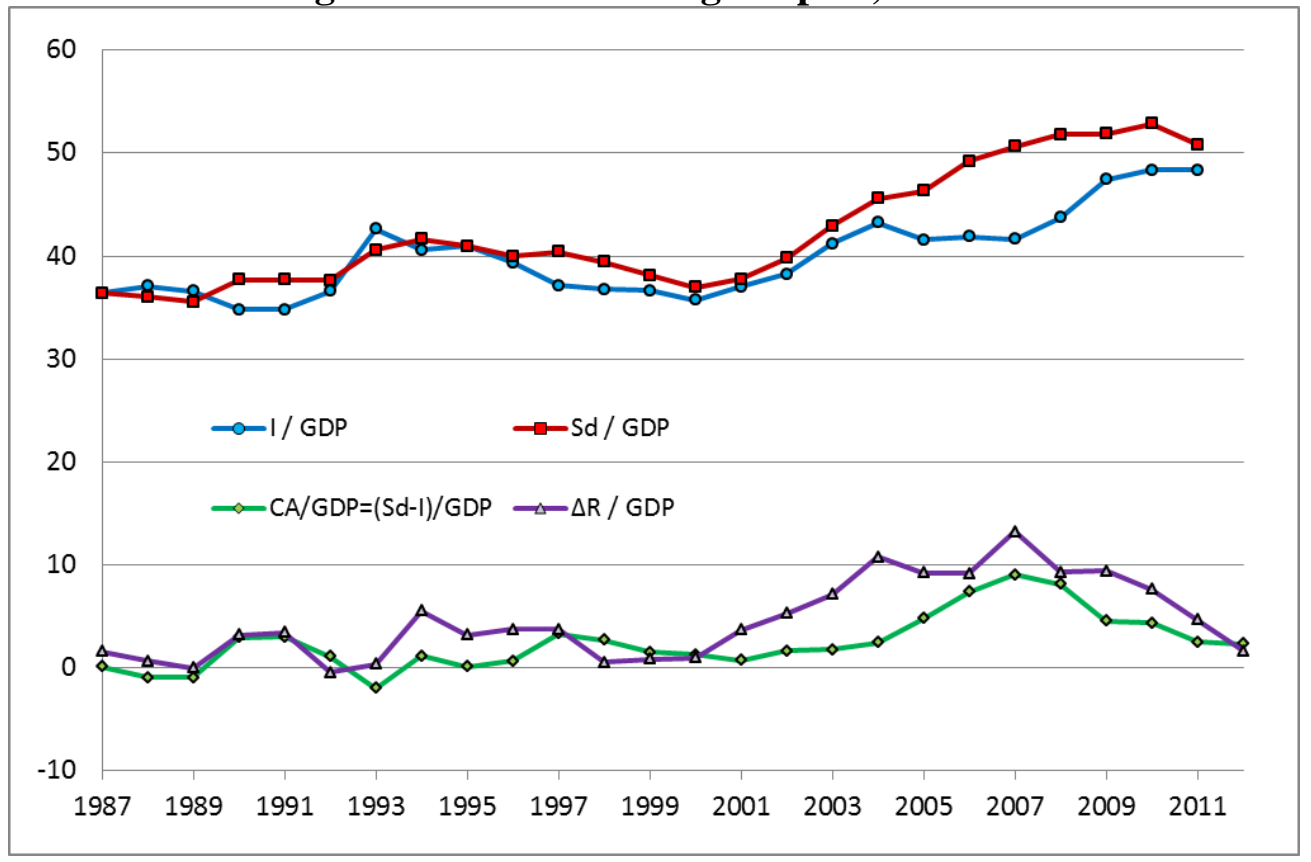

Sources: National Bureau of Statistics yearbook 2009-2012; IMF IFS data base. The value for the current account in 2012 is based on the trade balance and the authors' estimate of net factor income from abroad in that year. 
Table 1: Increments to Global, Asian and Chinese GDP and Saving 1980-2012:

\begin{tabular}{lcccc}
\hline & \multicolumn{2}{c}{$1980-2012$} & \multicolumn{2}{c}{ 1990-2012 } \\
\hline US\$ trillions & GDP & Saving & GDP & Saving \\
Share of Asia & 61 & 15 & 50 & 12 \\
Share of China & 30 & 46 & 32 & 47 \\
\hline
\end{tabular}

Source: IMF, World Economic Database.

Table 2: Relative Economic Sizes of China and the Other Large Regions, ca 2011:

\begin{tabular}{lllll}
\hline \multicolumn{1}{c}{ \% of world } & China & US & EU(26) & Japan \\
\hline GDP & 11 & 22 & 26 & 9 \\
Consumption, $C$ & 8 & 27 & 26 & 9 \\
Investment, $I$ & 20 & 15 & 22 & 8 \\
Government spending, $G$ & 7 & 20 & 30 & 10 \\
Exports, $X$ & 17 & 17 & 25 & 7 \\
Imports, $M$ & 15 & 21 & 23 & 8 \\
Total domestic saving, $S^{D}$ & 19 & 13 & 20 & 9 \\
\hline
\end{tabular}

Sources: National accounts data supply most of the elements though adjustments have been required to ensure that current accounts sum to zero globally, as do capital/financial accounts. The IMF-IFS database is the major source but there is frequent resort to national statistical databases.

Table 3: Simulation Closures ${ }^{\mathrm{a}}$

\begin{tabular}{ll}
\hline Closure & \\
\hline $\begin{array}{c}\text { Labour market: } \\
\text { Keynesian } \\
\text { Neoclassical }\end{array}$ & $\begin{array}{l}\text { Exogenous nominal wage in the US, EU, Japan and China } \\
\text { Full employment of all factors everywhere }\end{array}$ \\
$\begin{array}{c}\text { Fiscal policy closure: } \\
\text { Keynesian } \\
\text { Neoclassical }\end{array}$ & $\begin{array}{l}\text { Exogenous nominal government spending in US, EU and Japan } \\
\text { Exogenous government saving everywhere }\end{array}$ \\
Monetary policy targets: $^{b}$ & Exogenous monetary base in every region $^{c}$
\end{tabular}

\footnotetext{
a Since the model is a system of non-linear simultaneous equations and more variables are specified than equations in the system, there is flexibility as to the choice of those to make exogenous and this choice mirrors assumptions about the behaviour of labour markets, fiscal deficits and monetary policy targets.

b Money is neutral in the neoclassical closure.

c Money supplies can be set to target price levels, nominal exchange rates or nominal GDP levels. Indeed, for the three large developed regions monetary policy could be set to the usual inflation target (a CPI expanding by 2-3\%) but those regions, and particularly Japan, failed to meet this target during China's pre-GFC growth phase and so the money supply is set exogenous and subjected to idiosyncratic shocks.
} 
Table 4: Experimental Shocks

\begin{tabular}{|c|c|c|c|}
\hline Scenari & & Shocks, \% & \\
\hline 1. & Continued export led & All shocks to China & \\
\hline & relative growth in & Productivity, $A^{Y}$ & 3 \\
\hline & 2011 with no policy & Consumption constant, $A^{C}$ & -7 \\
\hline & response abroad & Capital stock, $K$ & 5 \\
\hline & & Skill stock, S & 3 \\
\hline & & Nominal wage, ${ }^{a} W$ & 3 \\
\hline & & Monetary base, $M^{B}$ & 15 \\
\hline 2. & Continued export led & Shocks to China & \\
\hline & relative growth in & Productivity, $A^{Y}$ & 3 \\
\hline & 2011 with monetary & Consumption constant, $A^{C}$ & -7 \\
\hline & expansions at home & Capital stock, $K$ & 5 \\
\hline & and in the US, EU & Skill stock, S & 3 \\
\hline & and Japan & Nominal wage, ${ }^{a} W$ & 3 \\
\hline & & Monetary base, $M^{B}$ & 15 \\
\hline & & Other shocks & \\
\hline & & US monetary base, $M^{B}$ & 10 \\
\hline & & EU monetary base, $M^{B}$ & 10 \\
\hline & & Japan monetary base, $M^{B}$ & 6 \\
\hline 3. & China slower relative & Shocks to China & \\
\hline & growth with higher & Productivity, $A^{Y}$ & 1 \\
\hline & consumption share & Consumption constant, $A^{C}$ & 15 \\
\hline & and home monetary & Capital stock, $K$ & 2 \\
\hline & response, no policy & Skill stock, $S$ & 2 \\
\hline & response abroad & Nominal wage, ${ }^{a} \mathrm{~W}$ & 2 \\
\hline & & Monetary base, $M^{B}$ & 5 \\
\hline
\end{tabular}

a Nominal wages are endogenous in the neoclassical closure and so are not shocked. The Chinese nominal wage is shocked with the Keynesian closure only to allow for observe increases. 
Table 5: Chinese Growth Shocks with Neoclassical Closure: Simulation Results

\begin{tabular}{|c|c|c|c|c|}
\hline \% changes & US & $\mathrm{EU}(26)$ & Japan & China \\
\hline \multicolumn{5}{|c|}{ 1. China relative growth with monetary response in China but none abroad } \\
\hline Real bond yield, $r$ & -9.4 & -9.4 & -8.7 & -8.3 \\
\hline Consumer price level, $P^{C}$ & -6.6 & -6.6 & -4.7 & 3.5 \\
\hline Producer price level, $P^{P}$ & -6.3 & -7.1 & -5.2 & 4.6 \\
\hline GDP price level, $P^{Y}$ & -5.3 & -5.3 & -5.0 & 3.3 \\
\hline Nominal exchange rate $v$ US, $E$ & 0.0 & -0.5 & -3.4 & -10.3 \\
\hline Real exchange rate $v$ US, $e$ & 0.0 & -0.5 & -3.1 & -2.1 \\
\hline Saving/GDP, $S^{D} / Y$ & -46.5 & -23.7 & -16.7 & 10.2 \\
\hline Real consumption, $C / P^{C}$ & 7.8 & 7.7 & 4.4 & -2.9 \\
\hline Real investment, $I / P^{P}$ & -29.1 & -23.1 & -18.5 & 10.8 \\
\hline Production employment, $L$ & 0.0 & 0.0 & 0.0 & 0.0 \\
\hline Real output (GDP), $Y / P^{Y}$ & 0.0 & 0.0 & 0.0 & 6.3 \\
\hline Nominal income (GDP), $Y$ & -5.3 & -5.3 & -5.0 & 9.8 \\
\hline Real income $Y / P^{C}$ & 1.4 & 1.4 & -0.3 & 6.1 \\
\hline \multicolumn{5}{|c|}{ 2. China relative growth with monetary response in China and in US, EU, Japan } \\
\hline Real bond yield, $r$ & -16.0 & -15.6 & -15.6 & -15.3 \\
\hline Consumer price level, $P^{C}$ & -0.3 & -0.8 & -3.3 & -0.1 \\
\hline Producer price level, $P^{P}$ & 0.1 & 0.0 & -3.3 & 0.3 \\
\hline GDP price level, $P^{Y}$ & 0.4 & 0.6 & -3.1 & -0.4 \\
\hline Nominal exchange rate $v \cup S, E$ & 0.0 & 0.2 & 2.4 & -0.8 \\
\hline Real exchange rate $v$ US, $e$ & 0.0 & 0.4 & -1.2 & -1.6 \\
\hline Saving/GDP, $S^{D} / Y$ & -10.2 & -7.0 & -14.0 & 6.0 \\
\hline Real consumption, $C / P^{C}$ & 2.0 & 3.1 & 4.2 & 0.6 \\
\hline Real investment, $I / P^{P}$ & -8.7 & -8.1 & -13.6 & 9.1 \\
\hline Production employment, $L$ & 0.0 & 0.0 & 0.0 & 0.0 \\
\hline Real output (GDP), $Y / P^{Y}$ & 0.0 & 0.0 & 0.0 & 6.3 \\
\hline Nominal income (GDP), $Y$ & 0.4 & 0.6 & -3.1 & 5.8 \\
\hline Real income $Y / P^{C}$ & 0.6 & 1.4 & 0.2 & 6.0 \\
\hline
\end{tabular}

3. Post transition China relative growth with strong consumption and a Chinese monetary response

$\begin{array}{lcccc}\text { Real bond yield, } r & 4.1 & 4.2 & 3.8 & 9.2 \\ \text { Consumer price level, } P^{C} & 3.0 & 2.9 & 2.1 & 10.0 \\ \text { Producer price level, } P^{P} & 3.0 & 3.3 & 2.4 & 7.8 \\ \text { GDP price level, } P^{Y} & 2.5 & 2.6 & 2.3 & 8.3 \\ \text { Nominal exchange rate v US, } E & 0.0 & 0.3 & 1.6 & -6.3 \\ \text { Real exchange rate v US, } e & 0.0 & 0.3 & 1.4 & -1.1 \\ \text { Saving/GDP, } S^{D} / Y & 19.3 & 9.4 & 6.9 & -5.9 \\ \text { Real consumption, } C / P^{C} & -3.1 & -2.8 & -1.7 & 4.7 \\ \text { Real investment, } / / P^{P} & 11.9 & 9.0 & 7.3 & -0.4 \\ \text { Production employment, } L & 0.0 & 0.0 & 0.0 & 0.0 \\ \text { Real output (GDP), } Y / P^{Y} & \mathbf{0 . 0} & \mathbf{0 . 0} & \mathbf{0 . 0} & \mathbf{2 . 5} \\ \text { Nominal income (GDP), } Y & \mathbf{2 . 5} & \mathbf{2 . 6} & \mathbf{2 . 3} & \mathbf{1 1 . 0} \\ \text { Real income } Y / \mathbf{P}^{C} & \mathbf{- 0 . 5} & \mathbf{- 0 . 3} & \mathbf{0 . 3} & \mathbf{0 . 9}\end{array}$

a These results are from the model described in the text and the closures and shocks listed in Tables 3 and 4. 
Table 6: Chinese Growth Shocks with Keynesian Closure: Simulation Results

\begin{tabular}{|c|c|c|c|c|}
\hline \% changes & US & $\mathrm{EU}(26)$ & Japan & China \\
\hline \multicolumn{5}{|c|}{ 1. China relative growth with monetary response in China but none abroad } \\
\hline Real bond yield, $r$ & -9.4 & -9.4 & -7.0 & -12.5 \\
\hline Consumer price level, $P^{C}$ & -5.5 & -5.7 & -3.2 & 0.8 \\
\hline Producer price level, $P^{P}$ & -5.2 & -5.7 & -3.5 & 0.7 \\
\hline GDP price level, $P^{Y}$ & -4.3 & -4.2 & -3.3 & -0.2 \\
\hline Nominal exchange rate $v$ US, $E$ & 0.0 & -0.4 & -3.5 & -6.9 \\
\hline Real exchange rate $v$ US, $e$ & 0.0 & -0.3 & -2.5 & -2.9 \\
\hline Saving/GDP, $S^{D} / Y$ & -38.9 & -20.1 & -14.6 & 8.7 \\
\hline Real consumption, $C / P^{C}$ & 5.6 & 5.6 & 2.5 & 0.2 \\
\hline Real investment, $I / P^{P}$ & -27.3 & -22.3 & -18.0 & 12.4 \\
\hline Production employment, $L$ & -6.3 & -6.9 & -4.2 & 5.3 \\
\hline Real output (GDP), $Y / P^{Y}$ & -1.1 & -1.3 & -0.8 & 7.7 \\
\hline Nominal income (GDP), $Y$ & -5.4 & -5.4 & -4.1 & 7.5 \\
\hline Real income $Y / P^{C}$ & 0.14 & 0.27 & -0.9 & 6.7 \\
\hline \multicolumn{5}{|c|}{ 2. China relative growth with monetary response in China and in US, EU, Japan } \\
\hline Real bond yield, $r$ & -16.2 & -16.5 & -13.7 & -16.5 \\
\hline Consumer price level, $P^{C}$ & -0.3 & -0.9 & -1.9 & -1.0 \\
\hline Producer price level, $P^{P}$ & 0.0 & -0.4 & -1.8 & -1.1 \\
\hline GDP price level, $P^{Y}$ & 0.2 & 0.2 & -1.7 & -1.7 \\
\hline Nominal exchange rate $v \cup S, E$ & 0.0 & 0.3 & 1.2 & 0.1 \\
\hline Real exchange rate $v$ US, $e$ & 0.0 & 0.3 & -0.7 & -1.8 \\
\hline Saving/GDP, $S^{D} / Y$ & -8.5 & -5.1 & -10.8 & 5.7 \\
\hline Real consumption, $C / P^{C}$ & 2.0 & 2.9 & 2.5 & 1.8 \\
\hline Real investment, $I / P^{P}$ & -7.1 & -6.2 & -11.5 & 10.7 \\
\hline Production employment, $L$ & 0.0 & -0.5 & -2.2 & 2.8 \\
\hline Real output (GDP), $Y / P^{Y}$ & 0.0 & -0.1 & -0.4 & 7.1 \\
\hline Nominal income (GDP), $Y$ & 0.2 & 0.1 & -2.1 & 5.3 \\
\hline Real income $Y / P^{C}$ & 0.6 & 1.0 & -0.2 & 6.3 \\
\hline
\end{tabular}

3. Post transition China relative growth with strong consumption and a Chinese monetary response

$\begin{array}{lcccc}\text { Real bond yield, } r & 7.9 & 7.6 & 5.8 & -1.8 \\ \text { Consumer price level, } P^{C} & 4.7 & 4.1 & 2.4 & 4.1 \\ \text { Producer price level, } P^{P} & 4.7 & 4.8 & 3.0 & -0.1 \\ \text { GDP price level, } P^{Y} & 3.9 & 3.7 & 2.9 & 1.3 \\ \text { Nominal exchange rate v US, } E & 0.0 & 0.7 & 3.3 & 0.6 \\ \text { Real exchange rate v US, } e & 0.0 & 0.5 & 2.3 & -2.0 \\ \text { Saving/GDP, } S^{D} / Y & 32.2 & 15.1 & 11.7 & -9.0 \\ \text { Real consumption, } C / P^{C} & -3.9 & -3.0 & -1.4 & 9.5 \\ \text { Real investment, } I / P^{P} & 21.4 & 16.1 & 13.4 & -1.2 \\ \text { Production employment, } L & 5.7 & 5.8 & 3.7 & 0.5 \\ \text { Real output (GDP), } Y / P^{Y} & \mathbf{1 . 0} & \mathbf{1 . 0} & \mathbf{0 . 6} & \mathbf{2 . 6} \\ \text { Nominal income (GDP), } \boldsymbol{Y} & \mathbf{4 . 9} & \mathbf{4 . 7} & \mathbf{3 . 6} & \mathbf{3 . 9} \\ \text { Real income } Y / \boldsymbol{P}^{C} & \mathbf{0 . 3} & \mathbf{0 . 6} & \mathbf{1 . 2} & \mathbf{- 0 . 2}\end{array}$

a These results are from the model described in the text and the closures and shocks listed in Tables 3 and 4 . 
Table 7: Employment and Real Income Effects of China's Transition

\begin{tabular}{|c|c|c|c|c|}
\hline$\%$ changes & US & EU(26) & Japan & China \\
\hline \multicolumn{5}{|l|}{ Neoclassical analysis only } \\
\hline \multicolumn{5}{|l|}{ Real income $Y / P^{C}$} \\
\hline Chinese growth, no foreign monetary response & 1.4 & 1.4 & -0.3 & 6.1 \\
\hline Chinese growth, foreign monetary response & 0.6 & 1.4 & 0.2 & 6.0 \\
\hline Post-transition Chinese growth & -0.5 & -0.3 & 0.3 & 0.9 \\
\hline Difference due to the transition & -1.1 & -1.7 & 0.1 & -5.1 \\
\hline \multicolumn{5}{|l|}{ Including Keynesian effects } \\
\hline \multicolumn{5}{|l|}{ Pre-GFC Chinese growth without monetary response } \\
\hline Production employment, $L$ & -6.3 & -6.9 & -4.2 & 5.3 \\
\hline Real income $Y / P^{C}$ & 0.1 & 0.3 & -0.9 & 6.7 \\
\hline \multicolumn{5}{|l|}{ Pre-GFC Chinese growth with monetary response } \\
\hline Production employment, $L$ & 0.0 & -0.5 & -2.2 & 2.8 \\
\hline Real income $Y / P^{C}$ & 0.6 & 1.0 & -0.2 & 6.3 \\
\hline \multicolumn{5}{|l|}{ Post-transition Chinese growth } \\
\hline Production employment, $L$ & 5.7 & 5.8 & 3.7 & 0.5 \\
\hline Real income, $Y / P^{C}$ & 0.3 & 0.6 & 1.2 & -0.2 \\
\hline \multicolumn{5}{|l|}{ Difference due to the transition } \\
\hline Production employment, $L$ & 5.7 & 6.3 & 5.9 & -2.3 \\
\hline Real income, $Y / P^{C}$ & -0.3 & -0.4 & 1.3 & -6.5 \\
\hline
\end{tabular}

a These summaries are based on the detailed results in Tables 5 and 6. 


\section{Appendix 1: Model Analytics - The Conventional Components}

Key financial relationships are given in the main text. This appendix lists the more standard details of the model's specification.

Output is assumed to be Cobb-Douglas in the three primary factors, so that, for regions $i$, local output and the marginal product of capital are:

$$
y_{i}=A_{i}^{Y} L_{i}^{\beta_{i}^{L}} S_{i}^{\beta_{i}^{S}} K_{i}^{\beta_{i}^{K}}, \quad M P_{i}^{K}=\beta_{i}^{K} \frac{y_{i}}{K_{i}}=\left[A_{i}^{Y} \beta_{i}^{K} S_{i}^{\beta_{i}^{S}} K_{i}^{\beta_{i}^{K}-1}\right] L_{i}^{\beta_{L}}, \quad \beta_{i}^{L}+\beta_{i}^{S}+\beta_{i}^{K}=1 \forall i
$$

The real volume of output, $y$, is distinguished from nominal GDP, $Y=P^{Y} y$, where $P^{Y}$ is the GDP price level (deflator). The real production wages of unskilled and skilled workers depend conventionally on the corresponding marginal products.

$$
w_{i}=\frac{W_{i}}{P_{i}^{P}}=\beta_{i}^{L} \frac{y_{i}}{L_{i}}, \quad w_{i}^{S}=\frac{W_{i}^{S}}{P_{i}^{P}}=\beta_{i}^{S} \frac{y_{i}}{S_{i}}
$$

Here the upper case wages are nominal and the lower case real and $P^{P}$ is the producer price level.

Both direct and indirect tax revenues, $T^{D}$ and $T^{I}$, play key roles in the formulation. GDP at factor cost (or producer prices), $Y^{F C}$, is the total of direct payments to the collective household in return for the use of its factors. Region i's nominal GDP is then

$$
Y_{i}=Y_{i}^{F C}+T_{i}^{I}, \quad Y_{i}^{F C}=C_{i}+T_{i}^{D}+S_{i}^{P}
$$

This is the standard disposal identity for GDP, or the collective household budget, where $C$ is the total value of final consumption expenditure, including indirect taxes paid, and $S^{P}$ is private saving. The GDP price, $P^{Y}$, and the producer price, $P^{P}$, would be the same were it not for indirect taxes. In their presence we have:

(A4) $Y_{i}=P_{i}^{Y} y_{i}=P_{i}^{P} y_{i}+T_{i}^{I}$, so that $P_{i}^{Y}=P_{i}^{P}+\frac{T_{i}^{I}}{y_{i}}$.

\section{Direct tax}

Constant marginal direct tax rates, $t^{W}$ and $t^{K}$, apply to all labour and capital income. The corresponding "powers" of these rates are $\tau^{L}=\left(1+t^{L}\right)$ and $\tau^{K}=\left(1+t^{K}\right)$ and total direct tax revenue is: 


$$
T_{i}^{D}=t_{i}^{L}\left(W_{i} L_{k}+W_{i}^{S} S_{i}\right)+t_{i}^{K} P_{i}^{P} M P_{i}^{K} K_{i}
$$

Indirect tax revenue, $T^{I}$, depends on consumption and trade and so it will emerge later.

\section{Consumption}

Aggregate consumption expenditure, $C$, is a nominal sum but real consumption behaviour is motivated by real incomes and the real interest rate. Real consumption, (lower case) $c$, depends negatively on the real after-tax return on savings (the home bond yield, $r$ ) and positively on both current and expected future real disposable income:

$$
c_{i}=\frac{C_{i}}{P_{i}^{C}}=A_{i}^{C}\left(\frac{r_{i}}{\tau_{i}^{K}}\right)^{-\varepsilon_{i}^{C R}}\left(\frac{Y_{i}^{D}}{P_{i}^{C}}\right)^{\varepsilon_{i}^{C Y}}\left(\frac{Y_{i}^{D e}}{P_{i}^{C}\left[1+\pi_{i}^{e}\right]}\right)^{\varepsilon_{i}^{C Y}},
$$

where the expected inflation rate of consumer prices is $\pi^{e}$. To capture the home household's substitution between home and foreign products, real aggregate consumption in region $i$ is a CES composite of region i's consumption of products from all regions:

$$
c_{i}=\left(\sum_{j} \alpha_{i j} c_{i j}^{-\theta_{i}}\right)^{-\frac{1}{\theta_{i}}}
$$

The home household then chooses its mix of consumed products to minimise consumption expenditure in a way that accounts for home indirect tax rates, foreign export taxes and differing foreign product prices and exchange rates:

$$
C_{i}=P_{i}^{C} C_{i}=P_{i}^{P} \tau_{i}^{C} c_{i i}+\sum_{j} \tau_{i}^{C} \tau_{i}^{M} \tau_{j}^{X} c_{i j} P_{j}^{P} \frac{E_{j}}{E_{i}},
$$

where $\tau_{i}^{C}, \tau_{i}^{M}$ and $\tau_{j}^{X}$ are, respectively, the powers of region $i$ 's consumption and import taxes and the region of origin, $j$ 's export tax. $E_{i}$ is region $i$ 's nominal exchange rate, measured as US\$ per unit of home currency. ${ }^{38}$

Optimum consumption is consistent with an elasticity of substitution between home and foreign products of $\sigma_{i}=1 /\left(1+\theta_{i}\right)$. The Marshallian demands are then:

$$
c_{i i}=\alpha_{i i}^{\sigma_{i}} \frac{C_{i}}{P_{i}^{C}}\left[\frac{P_{i}^{P} \tau_{i}^{C}}{P_{i}^{C}}\right]^{-\sigma_{i}}, \quad c_{i j}=\alpha_{i j}^{\sigma_{i}} \frac{C_{i}}{P_{i}^{C}}\left[\frac{\tau_{i}^{C} \tau_{i}^{M} P_{j}^{P}\left(E_{j} / E_{i}\right)}{P_{i}^{C}}\right]^{-\sigma_{i}}, i \neq j
$$

\footnotetext{
${ }^{38}$ US currency is the numeraire in the model.
} 
Given these consumption volumes, the composite price of all consumption, or the consumer price level, emerges from the substitution of (A7) and (A9) in (A8) as:

(A10) $P_{i}^{C}=\tau_{i}^{C}\left[\alpha_{i i}^{\sigma_{i}}\left(P_{i}^{P}\right)^{1-\sigma_{i}}+\tau_{i}^{M} \sum_{j \neq i} \alpha_{i j}^{\sigma_{i}}\left\{\frac{P_{j}^{P} E_{j}}{E_{i}}\right\}^{1-\sigma_{i}}\right]^{\frac{1}{1-\sigma_{i}}}$

The global product balance

Each region's product is differentiated from the others and so global product balance stems from a version of the expenditure identity in real volume terms:

(A11) $y_{i}=\frac{I_{i}+G_{i}}{P_{i}^{P}}+\sum_{j} c_{j i}$,

where the final term is the sum of real consumption and real exports. Neither investors nor the government pay indirect taxes on their expenditure and so the price they face for the home product is the producer price, $P^{P}$. This equation solves indirectly for the producer prices.

Private saving

Households receive income amounting to GDP at factor cost, $Y^{F C}$. Their disposable nominal income is this sum less direct tax (6), and private saving is what remains after consumption expenditure (9) is further deducted.

(A12) $Y_{i}^{D}=P_{i}^{P} y_{i}-T_{i}^{D}, S_{i}^{P}=Y_{i}^{D}-C_{i}$

\section{Indirect tax revenue}

This includes revenue from consumption, import and export taxes:

(A13) $T_{i}^{C}=t_{i}^{C}\left(P_{i}^{P} c_{i i}+\sum_{j} \tau_{i}^{M} \tau_{j}^{X} c_{i j} P_{j}^{P} \frac{E_{j}}{E_{i}}\right)$,

(A14) $T_{i}^{M}=t_{i}^{M} M_{i}, \quad M_{i}=\sum_{j \neq i} \tau_{j}^{X} c_{i j} P_{j}^{P} \frac{E_{j}}{E_{i}}$,

(A15) $T_{i}^{X}=t_{i}^{X} X_{i}, \quad X_{i}=\sum_{j} c_{j i} P_{i}^{P}$,

(A16) $T_{i}^{I}=T_{i}^{C}+T_{i}^{M}+T_{i}^{X}, T_{i}=T_{i}^{D}+T_{i}^{I}$.

Government and total domestic saving 
This is government revenue less government expenditure, both measured net of direct transfers. To simplify the demand side, spending by the government is assumed to be directed only at home goods. ${ }^{39}$ It pays no taxes and so faces the home producer price $P^{P}$. Total domestic saving is then the sum of private and government savings in the home economy, in home currency.

(A17) $S_{i}^{D}=S_{i}^{P}+S_{i}^{G}=S_{i}^{P}+T^{D}+T^{I}-G$.

\section{Balance of payments}

The sum of net inflows of payments on the current account and net inflows on the capital and financial accounts, measured in a single (home) currency is zero:

$$
X_{i}-M_{i}+\sum_{j \neq i}\left(i_{j i}^{S} S_{j}^{D} \frac{E_{j}}{E_{i}}\right)-\sum_{j \neq i}\left(i_{i j}^{S} S_{i}^{D}\right)=0, \quad \forall i \neq " U S "
$$

Balance in the US is implied by balance in all the other regions. These equations determine the nominal exchange rates and, since these are defined relative to the US\$, that for the US is always unity $\left(E_{U S}=1\right)$.

\section{Real exchange rate}

Each region has a real exchange rate relative to the US that is the rate of exchange between regional product bundles. With the regions specified as single product economies this measure parallels the terms of trade. Both real and nominal exchange rates are expressed according to the financial convention, so that an appreciation is a rise in value.

$$
e_{i}=\frac{P_{i}^{Y}}{\left(\frac{P_{U S}^{Y}}{E_{i}}\right)}=E_{i} \frac{P_{i}^{Y}}{P_{U S}^{Y}}
$$

\section{Appendix 2: Model Database}

The structures of the regional economies are indicated in Table A1. They differ in important ways. The US has a high consumption share of GDP, China a low one. Necessarily, then, the US has a low saving share while China has a high one. Some regions are more dependent on indirect taxes than others, which makes a difference to the proportion of GDP made up of factor cost and hence the size of the household budget and the gap between producer and GDP

\footnotetext{
${ }^{39}$ In the model database, direct transfers are netted from direct tax revenue, so that $T$ - $G$ is the true fiscal surplus.
} 
prices. The EU is relatively dependent on indirect taxes, for example. Since these taxes (at least those accounted for in the model) fall most heavily on consumption, changes in saving behaviour have strong implications for fiscal deficits and, indirectly, for interest premia. Investment is larger in some than in others, being extraordinarily high in China. And then, of course there are the fiscal deficits that are largest in the US and Japan, and the current account surpluses or capital-financial account deficits in Japan and China, at least partly funding the very substantial deficit in the US.

Interactions between these large economies through trade are captured in the consumption expenditure matrix shown in Table A2. It is derived from the combination of national accounts with a matrix of trade flows. The flows are expenditures inclusive of indirect taxes, converted into the shares of total expenditure on goods and services by each country. Implicit, and consistent with the one-good per region model, is the assumption that investment and government spending make demands on the markets for home goods only. As it turns out, this assumption has important implications for the representation of China in the model. Since its consumption is comparatively low and its investment high, home products are mostly absorbed by investment and government spending and so China's consumption is distributed more evenly across regional goods than for the other economies. This suggests a case for an importdependent capital goods industry in the model.

The financial interactions between the regions are indicated by the saving-to-investment flows in Table A3. ${ }^{40}$ These show the expected Feldstein-Horioka (1980) behaviour but also that there are substantial financial interactions between the US, the EU and Japan in particular. The share of excess saving directed to the US might be expected to change due to the recent decline in reserve accumulation by China and its substitution with outward FDI that, most recently, has not been directed to the US (Tyers et al. 2013). Finally, a complete list of the behavioural parameters used in the model is provided in Table A4.

\section{Appendix 3: Model Operation}

Comparative static analysis using the model requires that a set of shocks be applied to exogenous policy variables or behavioural parameters. These "levers" are listed in Table A5. Associated closure choices available in the model are listed in Table A6. These allow the choice of labour market equilibrium, fiscal policy regime and the target of monetary policy.

\footnotetext{
${ }^{40}$ Bilateral flows represent only those associated with asset acquisitions. Factor income flows, which depend on prior foreign asset holdings and are uninteresting in this comparative static framework, are excluded.
} 
Table A1: Regional Economic Structure, 2011:

\begin{tabular}{ccccccc}
\hline \% of GDP & US & EU(26) & Japan & China & Australia & RoW \\
\hline$C$ & 0.712 & 0.580 & 0.605 & 0.450 & 0.536 & 0.550 \\
$I$ & 0.155 & 0.191 & 0.200 & 0.410 & 0.275 & 0.240 \\
$G$ & 0.171 & 0.217 & 0.204 & 0.114 & 0.177 & 0.199 \\
$X$ & 0.139 & 0.175 & 0.151 & 0.285 & 0.217 & 0.200 \\
$M$ & 0.177 & 0.163 & 0.161 & 0.259 & 0.204 & 0.189 \\
Indirect tax rev, $T^{I}$ & 0.144 & 0.235 & 0.047 & 0.125 & 0.070 & 0.130 \\
Direct tax rev, $T^{D}$ & 0.017 & 0.015 & 0.124 & 0.035 & 0.093 & 0.061 \\
Total tax rev, $T$ & 0.161 & 0.250 & 0.171 & 0.160 & 0.163 & 0.191 \\
Private saving, $S^{P}$ & 0.127 & 0.169 & 0.224 & 0.390 & 0.301 & 0.259 \\
Govt saving, $S^{G}$ & -0.010 & 0.034 & -0.034 & 0.046 & -0.013 & -0.008 \\
Total saving, $S^{D}$ & 0.155 & 0.191 & 0.200 & 0.410 & 0.275 & 0.240 \\
Monetary base, $M^{B}$ & 0.133 & 0.114 & 0.220 & 0.411 & 0.134 & 0.250 \\
Capital stock, $K$ & 3.317 & 3.414 & 4.239 & 2.740 & 4.027 & 2.000 \\
\hline
\end{tabular}

Sources: National accounts data supply most of the elements though adjustments have been required to ensure that current accounts sum to zero globally, as do capital/financial accounts. The IMF-IFS database is the major source but there is frequent resort to national statistical databases.

Table A2: Shares of Consumption by Region of Origin, 2011 $^{\mathrm{a}}$

\begin{tabular}{|c|c|c|c|c|c|c|}
\hline $\begin{array}{l}\text { \% of row } \\
\text { consn } \\
\text { expenditure }\end{array}$ & US & $\mathrm{EU}(26)$ & Japan & China & Australia & RoW \\
\hline US & 65.9 & 10.3 & 2.3 & 6.1 & 0.5 & 14.9 \\
\hline $\mathrm{EU}(26)$ & 12.0 & 43.9 & 2.9 & 11.2 & 0.6 & 29.4 \\
\hline Japan & 4.7 & 5.1 & 69.1 & 6.5 & 2.3 & 12.3 \\
\hline China & 10.4 & 18.2 & 11.2 & 17.6 & 4.5 & 38.1 \\
\hline Australia & 8.1 & 12.8 & 3.8 & 9.2 & 53.7 & 12.5 \\
\hline Rest of world & 14.4 & 22.0 & 3.9 & 10.6 & 1.0 & 48.1 \\
\hline
\end{tabular}

a These shares sum to 100 horizontally. They are based on the 2011 matrix of trade flows combined with consumption expenditure data in each region. The resulting matrix is inconsistent as between data sources and so a RAS algorithm is used to force consistency of bilateral elements with national accounts data. Sources: Implied trade flows are for 2011, drawn from the World Trade Organisation database. 
Table A3: Shares of Total Domestic Saving Directed to Investment in Each Region, 2011

\begin{tabular}{lcccccc}
\hline $\begin{array}{l}\text { \% of row total } \\
\text { saving }\end{array}$ & US & EU(26) & Japan & China & Australia & RoW \\
\hline US $^{\mathrm{b}}$ & 68.0 & 13.3 & 6.4 & 6.4 & 1.5 & 4.4 \\
EU(26) $^{\mathrm{c}}$ & 12.9 & 80.1 & 2.3 & 2.3 & 0.9 & 1.5 \\
Japan $^{\mathrm{d}}$ & 14.0 & 3.3 & 72.2 & 6.2 & 0.7 & 3.6 \\
China $^{\mathrm{c}}$ & 9.2 & 0.6 & 0.9 & 81.1 & 0.1 & 8.0 \\
Australia $^{\mathrm{e}}$ & 13.0 & 4.8 & 2.3 & 2.1 & 77.3 & 0.4 \\
Rest of world & 3.4 & 3.9 & 2.6 & 2.8 & 0.1 & 87.2 \\
\hline
\end{tabular}

a These shares sum to 100 horizontally. They are based on 2011 investment flows. The original flow matrix is inconsistent with data on saving and investment from national accounts and so a RAS algorithm is used to ensure that row and column sums are consistent with other data. The row sums of the flow matrix are total saving by region and the column sums are total investment by region. These sums are sourced from the IMF-IFS database and the World Bank database.

b USA: values are based on official statistics, BEA.

c EU and China: indirect information from USA, Australian and Japanese statistics.

d Japan: estimated based on FDI data, assuming investment outflow=FDI*1.6. The ratio 1.6 is that of USA reported inward investment from Japan divided by Japanese reported outward FDI to the USA.

e Australia: Australian Bureau of Statistics "International Investment Position, Australia: Supplementary Statistics, 2011".

$\mathrm{f} \mathrm{ROW}$ is a residual. Its saving is inferred from national accounts estimates and its investment abroad is determined to balance the matrix of financial flows. 
Table A4: Parameters

\begin{tabular}{|c|c|c|c|c|c|c|}
\hline & US & $\mathrm{EU}(26)$ & Japan & China & Australia & RoW \\
\hline \multicolumn{7}{|l|}{ Production shares $^{\mathrm{a}}$} \\
\hline Labour, $\beta^{L}$ & 0.18 & 0.18 & 0.18 & 0.26 & 0.18 & 0.24 \\
\hline Skill, $\beta^{S^{\prime}}$ & 0.47 & 0.47 & 0.47 & 0.24 & 0.47 & 0.21 \\
\hline Capital, $\beta^{K}$ & 0.35 & 0.35 & 0.35 & 0.50 & 0.35 & 0.55 \\
\hline \multicolumn{7}{|l|}{ Income tax rates ${ }^{b}$} \\
\hline$t^{L}=t^{S}=t^{K}$ & 0.02 & 0.02 & 0.13 & 0.04 & 0.10 & 0.07 \\
\hline \multicolumn{7}{|l|}{ Indirect tax rates ${ }^{c}$} \\
\hline$t^{C}$ & 0.20 & 0.40 & 0.05 & 0.20 & 0.10 & 0.15 \\
\hline$t^{M}$ & 0.15 & 0.43 & 0.11 & 0.19 & 0.11 & 0.31 \\
\hline$t^{X}$ & 0.00 & 0.00 & 0.00 & 0.00 & 0.00 & 0.00 \\
\hline \multicolumn{7}{|l|}{ Money parameters ${ }^{\mathrm{d}}$} \\
\hline Interest premium, $\varphi^{0}$ & 1.00 & 0.97 & 0.78 & 1.73 & 0.82 & 2.61 \\
\hline Reserve ratio, $\rho$ & 0.05 & 0.05 & 0.05 & 0.15 & 0.05 & 0.10 \\
\hline Cash ratio, $\mu$ & 0.08 & 0.10 & 0.17 & 0.21 & 0.10 & 0.20 \\
\hline \multicolumn{7}{|l|}{ Elasticities } \\
\hline$C$ to $r, \varepsilon^{C R}$ & 0.10 & 0.10 & 0.10 & 0.10 & 0.10 & 0.10 \\
\hline$C$ to $Y^{D}, \varepsilon^{C Y}$ & 0.94 & 1.03 & 0.82 & 0.93 & 1.25 & 0.88 \\
\hline$C_{i j} / C_{i k}$ to $P_{j}^{C} / P_{k}^{C}, \sigma_{i}$ & 2.00 & 2.00 & 2.00 & 2.00 & 2.00 & 2.00 \\
\hline$s_{i j}^{S} / s_{i k}^{S}$ to $r_{j}^{c e} / r_{k}^{c e}, \sigma_{i}^{I}$ & 2.00 & 2.00 & 2.00 & 2.00 & 2.00 & 2.00 \\
\hline Premium to $G / T, \phi_{i}$ & 1.00 & 1.00 & 1.00 & 1.00 & 1.00 & 1.00 \\
\hline$m^{D}$ to $y, \varepsilon^{M Y}$ & 1.00 & 1.00 & 1.00 & 1.00 & 1.00 & 1.00 \\
\hline$m^{D}$ to $r+\pi^{e}, \varepsilon^{M R}$ & 0.60 & 0.60 & 0.60 & 0.60 & 0.60 & 0.60 \\
\hline
\end{tabular}

a Production shares are based on demographic and occupational data from Tyers and Bain (2006), as well as estimates of factor incomes and capital stocks from the GTAP Database.

b These income tax rates are lower than observed because direct transfers and sovereign debt service are deducted from income tax revenue so that observed fiscal balances are consistent with $T-G$, where $G$ includes only expenditure on goods and services.

c Although export taxes appear in the modelling, no values are applied since such taxes are usually very indirect. To infer the rates for other indirect taxes, approximate rates are initially chosen for the consumption tax rate and the import tax rate is then determined for consistency with the data on indirect tax revenue. In regions where other indirect taxes are major contributors to revenue, this tends to inflate the values of $t^{C}$ and $t^{M}$.

$\mathrm{d}$ The money parameters are crude characterisations, made on the assumption that the EU behaves as if it had a single central bank to cover all 26 members. Money demand parameters stem from a survey of estimates used in other models (including McKibbin and Wilcoxen 1995, Knell and Stix 2006, Teles and Zhou 2005 and Tseng et al. 1994).

e Consumption elasticities are consistent with a variety of estimates in use in other models, both of marginal propensities and elasticities (including McKibbin and Wilcoxen 1995 and Jin 2011). 
Table A5: Exogenous Variables for Experimentation

\begin{tabular}{lll}
\hline Policy & Instrument & \\
\hline Tax rates & Labour income tax & $t_{L}$ \\
& Capital income tax & $t_{K}$ \\
& Consumption tax (GST) & $t_{C}$ \\
& Import tariff & $t_{M}$ \\
& Export tax & $t_{X}$ \\
Fiscal policy & Government spending or the & $G, S_{G}$ \\
& fiscal surplus, US\$ trillion & \\
Monetary policy & Monetary base, US\$ trillion & $M_{B}$ \\
& Reserve ratio & $\rho$ \\
Expectations factors & Consumer price inflation & $\pi^{e}$ \\
& Real appreciation & $\gamma^{e}$ \\
Productivity & Nominal disposable income & $Y^{D e}$ \\
Saving & TFP & $A^{Y}$ \\
\hline
\end{tabular}

Table A6: Closure Choices and Policy Regimes

\begin{tabular}{lll}
\hline & $\begin{array}{l}\text { In each case, holding fixed or } \\
\text { exogenous one of: }\end{array}$ & \\
\hline Labour market & Nominal wage & $W$ \\
Labour use & $L$ \\
Government & Nominal expenditure & $G$ \\
Fiscal surplus & $T-G$ \\
& Monetary base & $M^{B}$ \\
Conetary target & GDP price level level & $P^{C}$ \\
& Producer price level & $P^{Y}$ \\
& Exchange rate & $P^{P}$ \\
& Nominal GDP & $E$ \\
\hline
\end{tabular}


Editor, UWA Economics Discussion Papers:

Ernst Juerg Weber

Business School - Economics

University of Western Australia

35 Sterling Hwy

Crawley WA 6009

Australia

Email: ecoadmin@biz.uwa.edu.au

The Economics Discussion Papers are available at:

1980 - 2002: http://ecompapers.biz.uwa.edu.au/paper/PDF\%20of\%20Discussion\%20Papers/

Since 2001: http://ideas.repec.org/s/uwa/wpaper1.html

Since 2004: $\quad$ http://www.business.uwa.edu.au/school/disciplines/economics

\section{ECONOMICS DISCUSSION PAPERS}

2012

\begin{tabular}{|c|c|c|}
\hline $\begin{array}{l}\text { DP } \\
\text { NUMBER }\end{array}$ & AUTHORS & TITLE \\
\hline 12.01 & $\begin{array}{l}\text { Clements, K.W., Gao, G., and } \\
\text { Simpson, T. }\end{array}$ & $\begin{array}{l}\text { DISPARITIES IN INCOMES AND PRICES } \\
\text { INTERNATIONALLY }\end{array}$ \\
\hline 12.02 & Tyers, R. & $\begin{array}{l}\text { THE RISE AND ROBUSTNESS OF ECONOMIC FREEDOM } \\
\text { IN CHINA }\end{array}$ \\
\hline 12.03 & Golley, J. and Tyers, R. & $\begin{array}{l}\text { DEMOGRAPHIC DIVIDENDS, DEPENDENCIES AND } \\
\text { ECONOMIC GROWTH IN CHINA AND INDIA }\end{array}$ \\
\hline 12.04 & Tyers, R. & LOOKING INWARD FOR GROWTH \\
\hline 12.05 & Knight, K. and McLure, M. & THE ELUSIVE ARTHUR PIGOU \\
\hline 12.06 & McLure, M. & $\begin{array}{l}\text { ONE HUNDRED YEARS FROM TODAY: A. C. PIGOU'S } \\
\text { WEALTH AND WELFARE }\end{array}$ \\
\hline 12.07 & Khuu, A. and Weber, E.J. & HOW AUSTRALIAN FARMERS DEAL WITH RISK \\
\hline 12.08 & Chen, M. and Clements, K.W. & PATTERNS IN WORLD METALS PRICES \\
\hline 12.09 & Clements, K.W. & UWA ECONOMICS HONOURS \\
\hline 12.10 & Golley, J. and Tyers, R. & $\begin{array}{l}\text { CHINA'S GENDER IMBALANCE AND ITS ECONOMIC } \\
\text { PERFORMANCE }\end{array}$ \\
\hline 12.11 & Weber, E.J. & $\begin{array}{l}\text { AUSTRALIAN FISCAL POLICY IN THE AFTERMATH OF } \\
\text { THE GLOBAL FINANCIAL CRISIS }\end{array}$ \\
\hline 12.12 & Hartley, P.R. and Medlock III, K.B. & $\begin{array}{l}\text { CHANGES IN THE OPERATIONAL EFFICIENCY OF } \\
\text { NATIONAL OIL COMPANIES }\end{array}$ \\
\hline 12.13 & Li, L. & $\begin{array}{l}\text { HOW MUCH ARE RESOURCE PROJECTS WORTH? A } \\
\text { CAPITAL MARKET PERSPECTIVE }\end{array}$ \\
\hline 12.14 & Chen, A. and Groenewold, N. & $\begin{array}{l}\text { THE REGIONAL ECONOMIC EFFECTS OF A } \\
\text { REDUCTION IN CARBON EMISSIONS AND AN } \\
\text { EVALUATION OF OFFSETTING POLICIES IN CHINA }\end{array}$ \\
\hline 12.15 & Collins, J., Baer, B. and Weber, E.J. & $\begin{array}{l}\text { SEXUAL SELECTION, CONSPICUOUS CONSUMPTION } \\
\text { AND ECONOMIC GROWTH }\end{array}$ \\
\hline
\end{tabular}




\begin{tabular}{|c|c|c|}
\hline \multicolumn{3}{|c|}{$\begin{array}{l}\text { ECONOMICS DISCUSSION PAPERS } \\
2012\end{array}$} \\
\hline $\begin{array}{l}\text { DP } \\
\text { NUMBER }\end{array}$ & AUTHORS & TITLE \\
\hline 12.16 & Wu, Y. & TRENDS AND PROSPECTS IN CHINA'S R\&D SECTOR \\
\hline 12.17 & Cheong, T.S. and Wu, Y. & $\begin{array}{l}\text { INTRA-PROVINCIAL INEQUALITY IN CHINA: AN } \\
\text { ANALYSIS OF COUNTY-LEVEL DATA }\end{array}$ \\
\hline 12.18 & Cheong, T.S. & THE PATTERNS OF REGIONAL INEQUALITY IN CHINA \\
\hline 12.19 & Wu, Y. & $\begin{array}{l}\text { ELECTRICITY MARKET INTEGRATION: GLOBAL } \\
\text { TRENDS AND IMPLICATIONS FOR THE EAS REGION }\end{array}$ \\
\hline 12.20 & Knight, K. & $\begin{array}{l}\text { EXEGESIS OF DIGITAL TEXT FROM THE HISTORY OF } \\
\text { ECONOMIC THOUGHT: A COMPARATIVE } \\
\text { EXPLORATORY TEST }\end{array}$ \\
\hline 12.21 & Chatterjee, I. & $\begin{array}{l}\text { COSTLY REPORTING, EX-POST MONITORING, AND } \\
\text { COMMERCIAL PIRACY: A GAME THEORETIC } \\
\text { ANALYSIS }\end{array}$ \\
\hline 12.22 & Pen, S.E. & QUALITY-CONSTANT ILLICIT DRUG PRICES \\
\hline 12.23 & Cheong, T.S. and Wu, Y. & $\begin{array}{l}\text { REGIONAL DISPARITY, TRANSITIONAL DYNAMICS } \\
\text { AND CONVERGENCE IN CHINA }\end{array}$ \\
\hline 12.24 & Ezzati, P. & $\begin{array}{l}\text { FINANCIAL MARKETS INTEGRATION OF IRAN } \\
\text { WITHIN THE MIDDLE EAST AND WITH THE REST OF } \\
\text { THE WORLD }\end{array}$ \\
\hline 12.25 & Kwan, F., Wu, Y. and Zhuo, S. & $\begin{array}{l}\text { RE-EXAMINATION OF THE SURPLUS AGRICULTURAL } \\
\text { LABOUR IN CHINA }\end{array}$ \\
\hline 12.26 & Wu, Y. & R\&D BEHAVIOUR IN CHINESE FIRMS \\
\hline 12.27 & Tang, S.H.K. and Yung, L.C.W. & $\begin{array}{l}\text { MAIDS OR MENTORS? THE EFFECTS OF LIVE-IN } \\
\text { FOREIGN DOMESTIC WORKERS ON SCHOOL } \\
\text { CHILDREN'S EDUCATIONAL ACHIEVEMENT IN HONG } \\
\text { KONG }\end{array}$ \\
\hline 12.28 & Groenewold, N. & $\begin{array}{l}\text { AUSTRALIA AND THE GFC: SAVED BY ASTUTE } \\
\text { FISCAL POLICY? }\end{array}$ \\
\hline
\end{tabular}




\section{ECONOMICS DISCUSSION PAPERS}

2013

\begin{tabular}{|c|c|c|}
\hline $\begin{array}{l}\text { DP } \\
\text { NUMBER }\end{array}$ & AUTHORS & TITLE \\
\hline 13.01 & $\begin{array}{l}\text { Chen, M., Clements, K.W. and } \\
\text { Gao, G. }\end{array}$ & THREE FACTS ABOUT WORLD METAL PRICES \\
\hline 13.02 & Collins, J. and Richards, O. & $\begin{array}{l}\text { EVOLUTION, FERTILITY AND THE AGEING } \\
\text { POPULATION }\end{array}$ \\
\hline 13.03 & $\begin{array}{l}\text { Clements, K., Genberg, H., } \\
\text { Harberger, A., Lothian, J., } \\
\text { Mundell, R., Sonnenschein, H. and } \\
\text { Tolley, G. }\end{array}$ & LARRY SJAASTAD, 1934-2012 \\
\hline 13.04 & Robitaille, M.C. and Chatterjee, I. & MOTHERS-IN-LAW AND SON PREFERENCE IN INDIA \\
\hline 13.05 & Clements, K.W. and Izan, I.H.Y. & $\begin{array}{l}\text { REPORT ON THE } 25^{\mathrm{TH}} \text { PHD CONFERENCE IN } \\
\text { ECONOMICS AND BUSINESS }\end{array}$ \\
\hline 13.06 & Walker, A. and Tyers, R. & QUANTIFYING AUSTRALIA’S “THREE SPEED” BOOM \\
\hline 13.07 & Yu, F. and Wu, Y. & PATENT EXAMINATION AND DISGUISED PROTECTION \\
\hline 13.08 & $\mathrm{Yu}, \mathrm{F}$. and $\mathrm{Wu}, \mathrm{Y}$. & $\begin{array}{l}\text { PATENT CITATIONS AND KNOWLEDGE SPILLOVERS: } \\
\text { AN ANALYSIS OF CHINESE PATENTS REGISTER IN } \\
\text { THE US }\end{array}$ \\
\hline 13.09 & Chatterjee, I. and Saha, B. & BARGAINING DELEGATION IN MONOPOLY \\
\hline 13.10 & Cheong, T.S. and Wu, Y. & $\begin{array}{l}\text { GLOBALIZATION AND REGIONAL INEQUALITY IN } \\
\text { CHINA }\end{array}$ \\
\hline 13.11 & Cheong, T.S. and Wu, Y. & INEQUALITY AND CRIME RATES IN CHINA \\
\hline 13.12 & Robertson, P.E. and Ye, L. & ON THE EXISTENCE OF A MIDDLE INCOME TRAP \\
\hline 13.13 & Robertson, P.E. & THE GLOBAL IMPACT OF CHINA’S GROWTH \\
\hline 13.14 & $\begin{array}{l}\text { Hanaki, N., Jacquemet, N., } \\
\text { Luchini, S., and Zylbersztejn, A. }\end{array}$ & $\begin{array}{l}\text { BOUNDED RATIONALITY AND STRATEGIC } \\
\text { UNCERTAINTY IN A SIMPLE DOMINANCE SOLVABLE } \\
\text { GAME }\end{array}$ \\
\hline 13.15 & $\begin{array}{l}\text { Okatch, Z., Siddique, A. and } \\
\text { Rammohan, A. }\end{array}$ & $\begin{array}{l}\text { DETERMINANTS OF INCOME INEQUALITY IN } \\
\text { BOTSWANA }\end{array}$ \\
\hline 13.16 & Clements, K.W. and Gao, G. & $\begin{array}{l}\text { A MULTI-MARKET APPROACH TO MEASURING THE } \\
\text { CYCLE }\end{array}$ \\
\hline 13.17 & Chatterjee, I. and Ray, R. & $\begin{array}{l}\text { THE ROLE OF INSTITUTIONS IN THE INCIDENCE OF } \\
\text { CRIME AND CORRUPTION }\end{array}$ \\
\hline 13.18 & Fu, D. and $\mathrm{Wu}, \mathrm{Y}$. & $\begin{array}{l}\text { EXPORT SURVIVAL PATTERN AND DETERMINANTS } \\
\text { OF CHINESE MANUFACTURING FIRMS }\end{array}$ \\
\hline 13.19 & Shi, X., Wu, Y. and Zhao, D. & $\begin{array}{l}\text { KNOWLEDGE INTENSIVE BUSINESS SERVICES AND } \\
\text { THEIR IMPACT ON INNOVATION IN CHINA }\end{array}$ \\
\hline 13.20 & $\begin{array}{l}\text { Tyers, R., Zhang, Y. and } \\
\text { Cheong, T.S. }\end{array}$ & $\begin{array}{l}\text { CHINA’S SAVING AND GLOBAL ECONOMIC } \\
\text { PERFORMANCE }\end{array}$ \\
\hline 13.21 & Collins, J., Baer, B. and Weber, E.J. & $\begin{array}{l}\text { POPULATION, TECHNOLOGICAL PROGRESS AND THE } \\
\text { EVOLUTION OF INNOVATIVE POTENTIAL }\end{array}$ \\
\hline 13.22 & Hartley, P.R. & THE FUTURE OF LONG-TERM LNG CONTRACTS \\
\hline 13.23 & Tyers, R. & $\begin{array}{l}\text { A SIMPLE MODEL TO STUDY GLOBAL } \\
\text { MACROECONOMIC INTERDEPENDENCE }\end{array}$ \\
\hline
\end{tabular}




\begin{tabular}{|c|c|c|}
\hline \multicolumn{3}{|c|}{$\begin{array}{c}\text { ECONOMICS DISCUSSION PAPERS } \\
2013\end{array}$} \\
\hline $\begin{array}{l}\text { DP } \\
\text { NUMBER }\end{array}$ & AUTHORS & TITLE \\
\hline 13.24 & McLure, M. & $\begin{array}{l}\text { REFLECTIONS ON THE QUANTITY THEORY: PIGOU IN } \\
1917 \text { AND PARETO IN 1920-21 }\end{array}$ \\
\hline 13.25 & Chen, A. and Groenewold, N. & $\begin{array}{l}\text { REGIONAL EFFECTS OF AN EMISSIONS-REDUCTION } \\
\text { POLICY IN CHINA: THE IMPORTANCE OF THE } \\
\text { GOVERNMENT FINANCING METHOD }\end{array}$ \\
\hline 13.26 & Siddique, M.A.B. & $\begin{array}{l}\text { TRADE RELATIONS BETWEEN AUSTRALIA AND } \\
\text { THAILAND: } 1990 \text { TO } 2011\end{array}$ \\
\hline 13.27 & Li, B. and Zhang, J. & $\begin{array}{l}\text { GOVERNMENT DEBT IN AN INTERGENERATIONAL } \\
\text { MODEL OF ECONOMIC GROWTH, ENDOGENOUS } \\
\text { FERTILITY, AND ELASTIC LABOR WITH AN } \\
\text { APPLICATION TO JAPAN }\end{array}$ \\
\hline 13.28 & Robitaille, M. and Chatterjee, I. & $\begin{array}{l}\text { SEX-SELECTIVE ABORTIONS AND INFANT } \\
\text { MORTALITY IN INDIA: THE ROLE OF PARENTS' } \\
\text { STATED SON PREFERENCE }\end{array}$ \\
\hline 13.29 & Ezzati, P. & $\begin{array}{l}\text { ANALYSIS OF VOLATILITY SPILLOVER EFFECTS: } \\
\text { TWO-STAGE PROCEDURE BASED ON A MODIFIED } \\
\text { GARCH-M }\end{array}$ \\
\hline 13.30 & Robertson, P. E. & $\begin{array}{l}\text { DOES A FREE MARKET ECONOMY MAKE AUSTRALIA } \\
\text { MORE OR LESS SECURE IN A GLOBALISED WORLD? }\end{array}$ \\
\hline 13.31 & $\begin{array}{l}\text { Das, S., Ghate, C. and } \\
\text { Robertson, P. E. }\end{array}$ & $\begin{array}{l}\text { REMOTENESS AND UNBALANCED GROWTH: } \\
\text { UNDERSTANDING DIVERGENCE ACROSS INDIAN } \\
\text { DISTRICTS }\end{array}$ \\
\hline 13.32 & Robertson, P.E. and Sin, A. & $\begin{array}{l}\text { MEASURING HARD POWER: CHINA'S ECONOMIC } \\
\text { GROWTH AND MILITARY CAPACITY }\end{array}$ \\
\hline 13.33 & Wu, Y. & $\begin{array}{l}\text { TRENDS AND PROSPECTS FOR THE RENEWABLE } \\
\text { ENERGY SECTOR IN THE EAS REGION }\end{array}$ \\
\hline 13.34 & $\begin{array}{l}\text { Yang, S., Zhao, D., Wu, Y. and } \\
\text { Fan, J. }\end{array}$ & $\begin{array}{l}\text { REGIONAL VARIATION IN CARBON EMISSION AND } \\
\text { ITS DRIVING FORCES IN CHINA: AN INDEX } \\
\text { DECOMPOSITION ANALYSIS }\end{array}$ \\
\hline
\end{tabular}




\section{ECONOMICS DISCUSSION PAPERS}

2014

\begin{tabular}{|c|c|c|}
\hline $\begin{array}{l}\text { DP } \\
\text { NUMBER }\end{array}$ & AUTHORS & TITLE \\
\hline 14.01 & $\begin{array}{l}\text { Boediono, Vice President of the Republic } \\
\text { of Indonesia }\end{array}$ & $\begin{array}{l}\text { THE CHALLENGES OF POLICY MAKING IN A } \\
\text { YOUNG DEMOCRACY: THE CASE OF INDONESIA } \\
\text { (52ND SHANN MEMORIAL LECTURE, 2013) }\end{array}$ \\
\hline 14.02 & Metaxas, P.E. and Weber, E.J. & $\begin{array}{l}\text { AN AUSTRALIAN CONTRIBUTION TO } \\
\text { INTERNATIONAL TRADE THEORY: THE } \\
\text { DEPENDENT ECONOMY MODEL }\end{array}$ \\
\hline 14.03 & Fan, J., Zhao, D., Wu, Y. and Wei, J. & $\begin{array}{l}\text { CARBON PRICING AND ELECTRICITY MARKET } \\
\text { REFORMS IN CHINA }\end{array}$ \\
\hline 14.04 & McLure, M. & $\begin{array}{l}\text { A.C. PIGOU’S MEMBERSHIP OF THE } \\
\text { 'CHAMBERLAIN-BRADBURY’ COMMITTEE. } \\
\text { PART I: THE HISTORICAL CONTEXT }\end{array}$ \\
\hline 14.05 & McLure, M. & $\begin{array}{l}\text { A.C. PIGOU’S MEMBERSHIP OF THE } \\
\text { ‘CHAMBERLAIN-BRADBURY’ COMMITTEE. } \\
\text { PART II: ‘TRANSITIONAL’AND ‘ONGOING’ ISSUES }\end{array}$ \\
\hline 14.06 & King, J.E. and McLure, M. & HISTORY OF THE CONCEPT OF VALUE \\
\hline 14.07 & Williams, A. & $\begin{array}{l}\text { A GLOBAL INDEX OF INFORMATION AND } \\
\text { POLITICAL TRANSPARENCY }\end{array}$ \\
\hline 14.08 & Knight, K. & $\begin{array}{l}\text { A.C. PIGOU'S THE THEORY OF UNEMPLOYMENT } \\
\text { AND ITS CORRIGENDA: THE LETTERS OF } \\
\text { MAURICE ALLEN, ARTHUR L. BOWLEY, RICHARD } \\
\text { KAHN AND DENNIS ROBERTSON }\end{array}$ \\
\hline 14.09 & Cheong, T.S. and Wu, Y. & $\begin{array}{l}\text { THE IMPACTS OF STRUCTURAL RANSFORMATION } \\
\text { AND INDUSTRIAL UPGRADING ON REGIONAL } \\
\text { INEQUALITY IN CHINA }\end{array}$ \\
\hline 14.10 & $\begin{array}{l}\text { Chowdhury, M.H., Dewan, M.N.A., } \\
\text { Quaddus, M., Naude, M. and } \\
\text { Siddique, A. }\end{array}$ & $\begin{array}{l}\text { GENDER EQUALITY AND SUSTAINABLE } \\
\text { DEVELOPMENT WITH A FOCUS ON THE COASTAL } \\
\text { FISHING COMMUNITY OF BANGLADESH }\end{array}$ \\
\hline 14.11 & Bon, J. & $\begin{array}{l}\text { UWA DISCUSSION PAPERS IN ECONOMICS: THE } \\
\text { FIRST } 750\end{array}$ \\
\hline 14.12 & Finlay, K. and Magnusson, L.M. & $\begin{array}{l}\text { BOOTSTRAP METHODS FOR INFERENCE WITH } \\
\text { CLUSTER-SAMPLE IV MODELS }\end{array}$ \\
\hline 14.13 & Chen, A. and Groenewold, N. & $\begin{array}{l}\text { THE EFFECTS OF MACROECONOMIC SHOCKS ON } \\
\text { THE DISTRIBUTION OF PROVINCIAL OUTPUT IN } \\
\text { CHINA: ESTIMATES FROM A RESTRICTED VAR } \\
\text { MODEL }\end{array}$ \\
\hline 14.14 & Hartley, P.R. and Medlock III, K.B. & $\begin{array}{l}\text { THE VALLEY OF DEATH FOR NEW ENERGY } \\
\text { TECHNOLOGIES }\end{array}$ \\
\hline 14.15 & $\begin{array}{l}\text { Hartley, P.R., Medlock III, K.B., } \\
\text { Temzelides, T. and Zhang, X. }\end{array}$ & $\begin{array}{l}\text { LOCAL EMPLOYMENT IMPACT FROM COMPETING } \\
\text { ENERGY SOURCES: SHALE GAS VERSUS WIND } \\
\text { GENERATION IN TEXAS }\end{array}$ \\
\hline 14.16 & Tyers, R. and Zhang, Y. & $\begin{array}{l}\text { SHORT RUN EFFECTS OF THE ECONOMIC REFORM } \\
\text { AGENDA }\end{array}$ \\
\hline 14.17 & Clements, K.W., Si, J. and Simpson, T. & UNDERSTANDING NEW RESOURCE PROJECTS \\
\hline 14.18 & Tyers, R. & $\begin{array}{l}\text { SERVICE OLIGOPOLIES AND AUSTRALIA'S } \\
\text { ECONOMY-WIDE PERFORMANCE }\end{array}$ \\
\hline
\end{tabular}




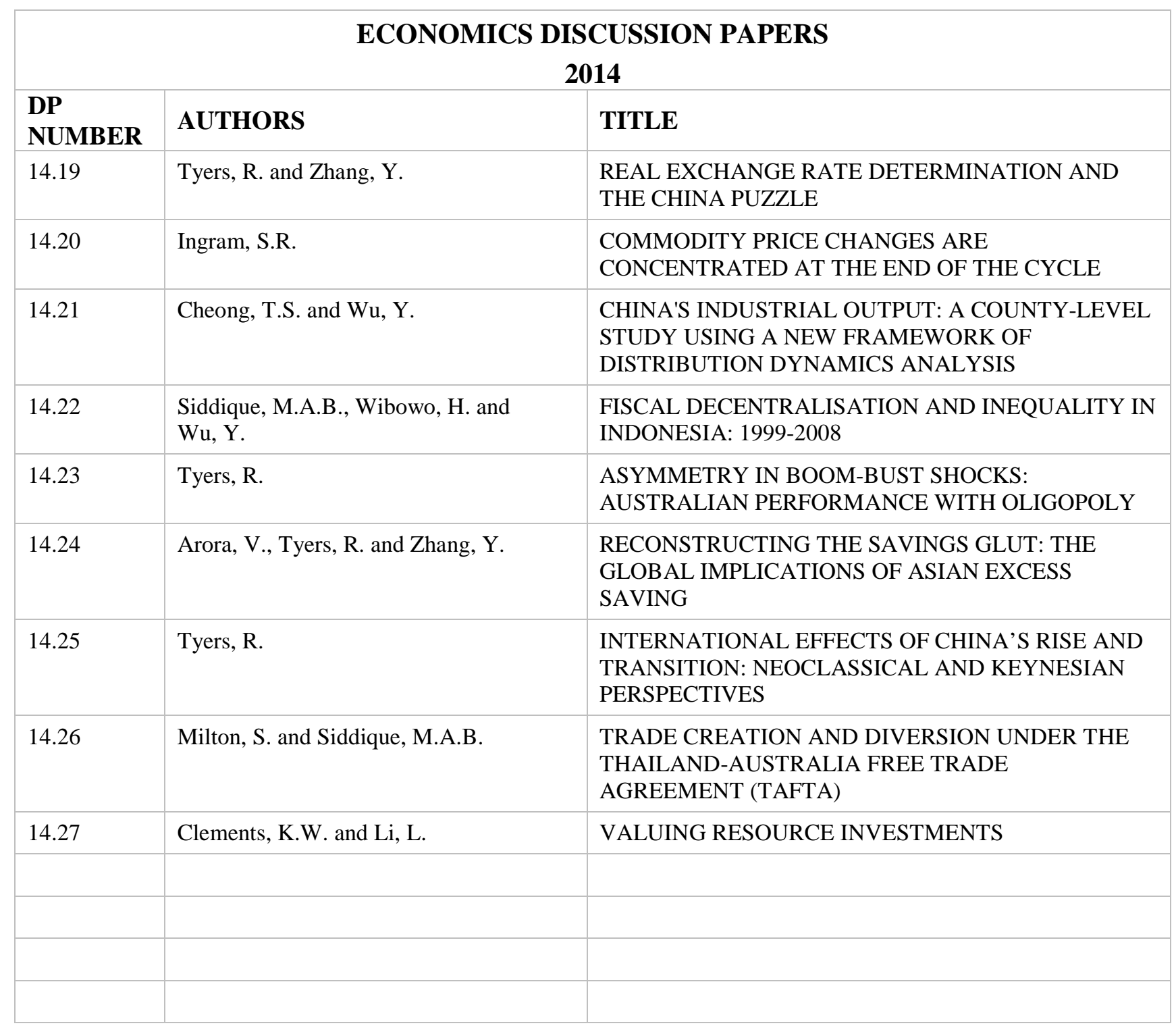

